FINDING A PLACE TO CALL HOME:

THE EXPERIENCE OF FRONTLINE WORKERS SEARCHING FOR HOUSING FOR REFUGEE CLAIMANTS IN TORONTO

by

River Ariel Shaw, BA, University of Ottawa, 2013

A Major Research Paper presented to Ryerson University in partial fulfillment of the requirements for the degree of

\author{
Master of Arts \\ in the Program of \\ Immigration and Settlement Studies
}

Toronto, Ontario, Canada, 2017

(c) River Ariel Shaw, 2017 


\section{AUTHOR'S DECLARATION FOR ELECTRONIC SUBMISSION OF A MAJOR RESEARCH PAPER (MRP)}

I hereby declare that I am the sole author of this Major Research Paper. This is a true copy of the MRP, including any required final revisions.

I authorize Ryerson University to lend this MRP to other institutions or individuals for the purpose of scholarly research.

I further authorize Ryerson University to reproduce this MRP by photocopying or by other means, in total or in part, at the request of other institutions or individuals for the purpose of scholarly research.

I understand that my MRP may be made electronically available to the public.

River A Shaw 


\title{
FINDING A PLACE TO CALL HOME: THE EXPERIENCE OF FRONTLINE WORKERS SEARCHING FOR HOUSING FOR REFUGEE CLAIMANTS IN TORONTO
}

\author{
River Ariel Shaw \\ Master of Arts 2017 \\ Immigration and Settlement Studies \\ Ryerson University
}

\begin{abstract}
This qualitative research paper examines the roles of frontline workers who work in refugeespecific shelters in Toronto, and whose tasks involve finding housing for refugee claimants. Four participants from different shelters were interviewed and were asked about the barriers that they face when fulfilling this role. These types of barriers are those that FLWs experience on behalf of their clients, in addition to barriers that FLWs experience in their workplace which can impact the success of their work. This paper reflects on these findings using an Anti-Oppressive Practice framework. Findings reveal that the participants experience a range of discrimination against their clients by landlords, in addition to stigma surrounding unemployment, welfare recipients, and newcomers. Participants also face difficulties fulfilling their client's expectations of housing that is available in Toronto. Furthermore, participants face barriers at their workplace such as working over time and being understaffed.
\end{abstract}

Keywords: Refugee claimants, frontline workers, housing, Toronto 


\section{Acknowledgements}

First and foremost, I would like to sincerely thank my supervisor Dr. Idil Atak, for the contribution of her time, her constructive observations, and the guidance she provided throughout the writing process of this paper. Her input has been greatly appreciated.

Secondly, I would like to thank my dedicated second reader Dr. John Shields, for the commitment of his time and his considerate validation of my analysis.

Thirdly, I would like to thank the four diligent and committed participants who took the time out of their own busy schedules to voluntarily contribute their participation to my study. Each of you carry out such critical humanitarian work for the refugee population and the Toronto community at large. I appreciated your willingness to selflessly share with me the details of your employment duties, responsibilities, and the challenges therein. Your collaboration was invaluable to the completion of this paper.

Finally, I would like to acknowledge with much gratitude my loving and devoted partner Mark Milloy. His persistent encouragement, selfless support, endless positive pep talks, and dedication to infinite edits and revisions all contributed to helping me retain my motivation and stay on track over the past year of completing this Master's Degree. I would also like to give a big loud "thank - you" to the family and friends who provided me with love, support, and encouragement along the way. You know who you are. 


\section{Table of Contents}

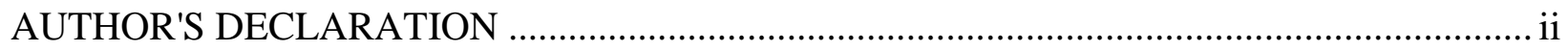

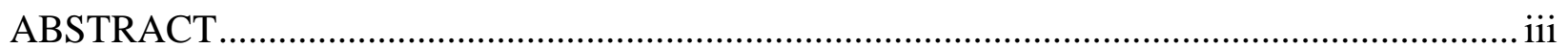

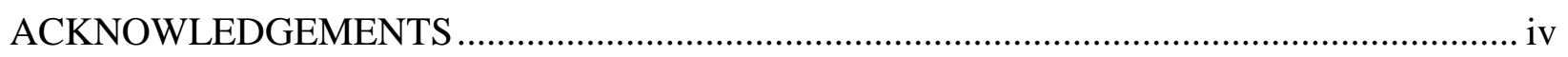

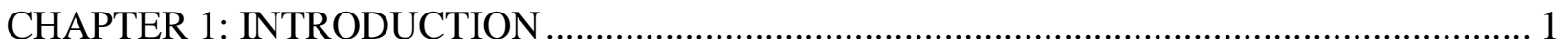

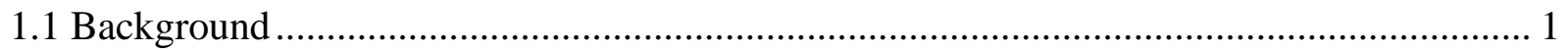

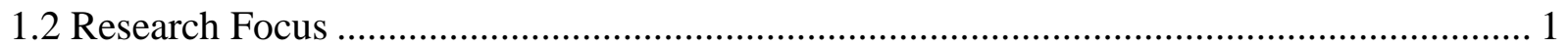

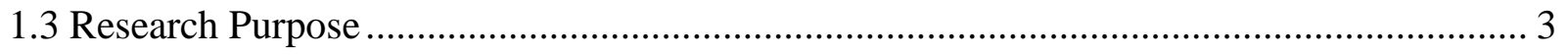

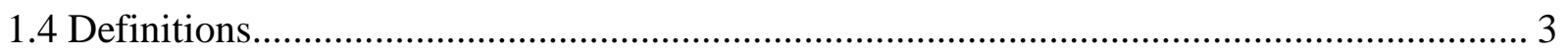

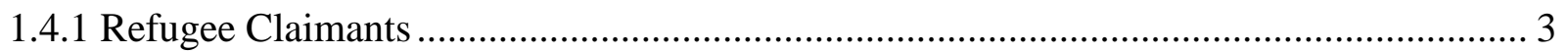

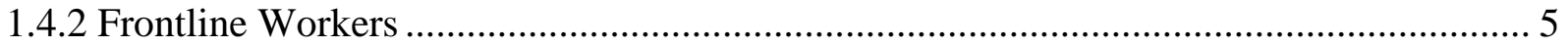

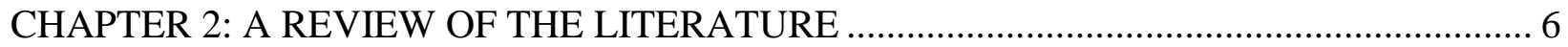

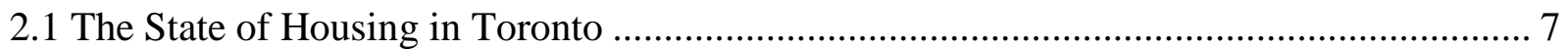

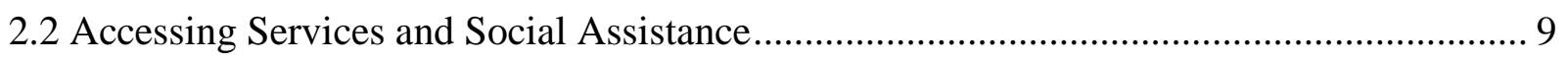

2.3 Barriers in Access to Housing................................................................................... 10

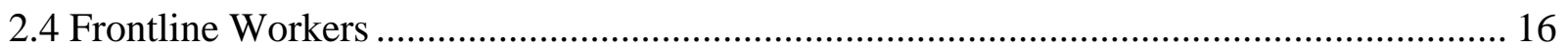

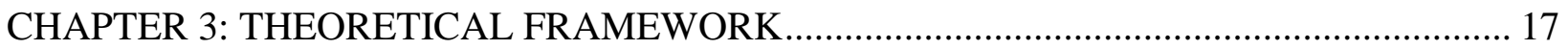

3.1 Understanding Anti-Oppressive Practice.................................................................... 17

3.2 Applying Anti-Oppressive Practice to Canada's Refugee System ...................................... 20

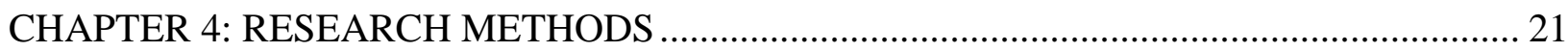

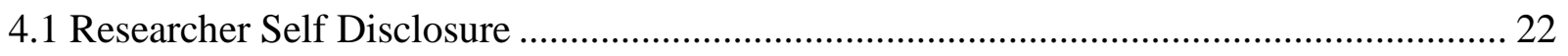

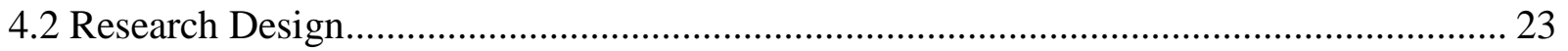

4.3 Participant Selection and Recruitment.................................................................... 23

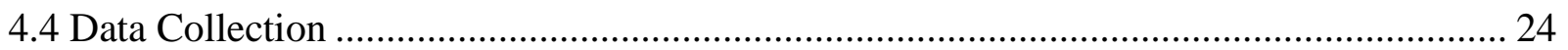

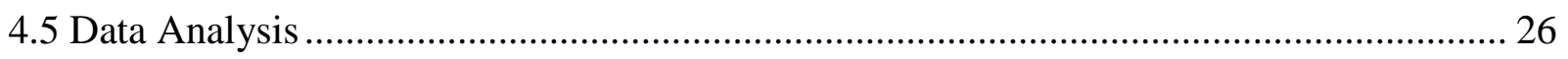

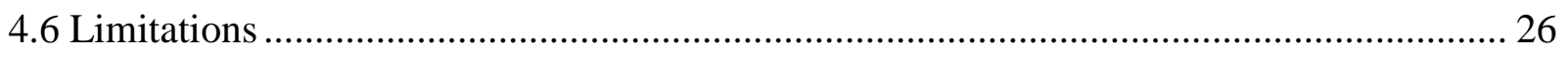

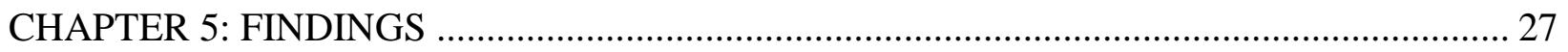

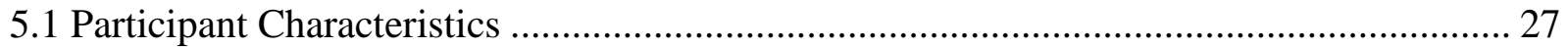

5.2 Defining Participants Roles in Refugee Shelters ........................................................ 28

5.3 Finding Accommodation in Toronto for Refugee Claimants ........................................... 29

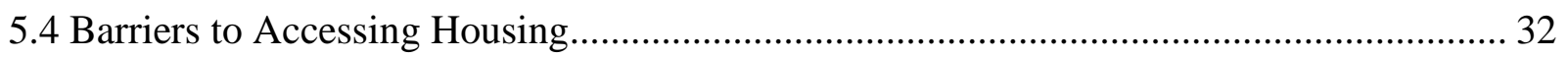

5.4.1 Lack of Affordable Housing .................................................................................... 32 
5.4.2 Discrimination and Xenophobia from Landlords ............................................... 33

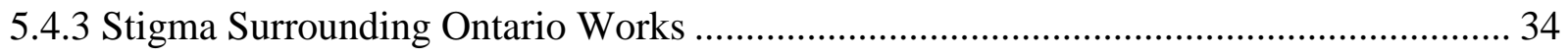

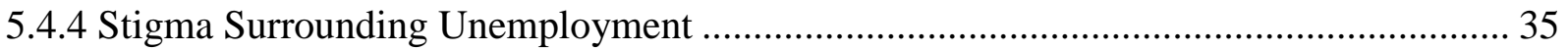

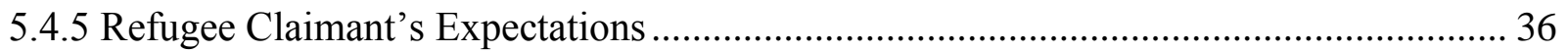

5.5 How the Housing Search Affects Participants' Clients ................................................ 37

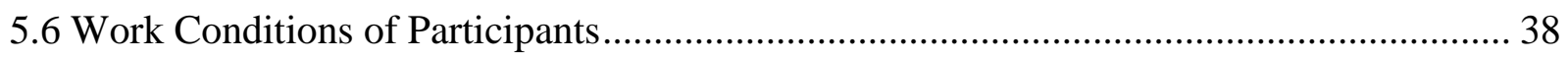

5.7 Participants' Policy Recommendations ...................................................................... 41

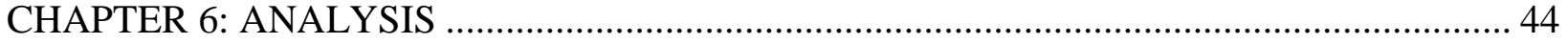

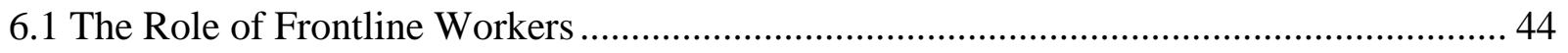

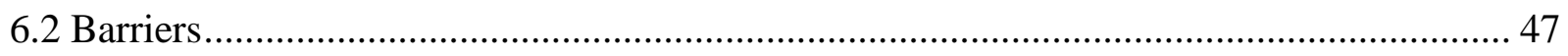

6.2.1 Lack of Subsidized and Affordable Housing ........................................................... 48

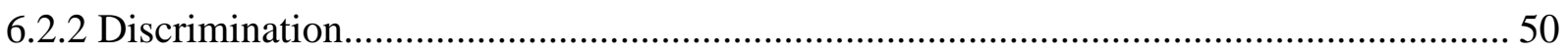

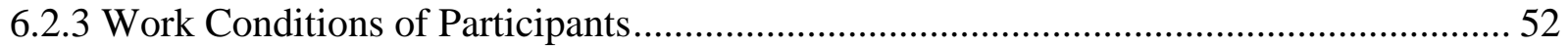

6.3 Participant's Attitudes and Reflections......................................................................... 53

CHAPTER 7: POLICY RECOMMENDATIONS ............................................................ 54

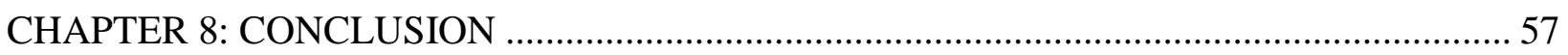

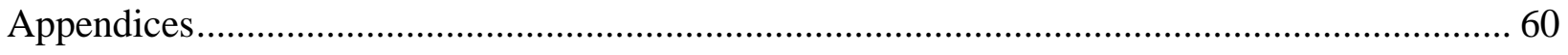

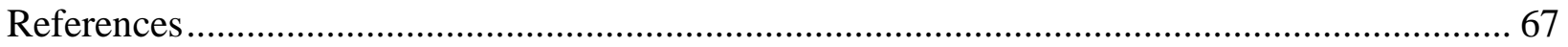




\section{CHAPTER 1: INTRODUCTION}

\subsection{Background}

In Canada, unlike government and privately sponsored refugees, "[t]here is no system in place to welcome or assist refugee claimants" (Matthew House, n.d.). Refugee claimants, who must find and fund their own way to Canada, are the only group of refugees who do not have housing arranged before they arrive (Matthew House, n.d.). They are often homeless during their initial days, or live in city shelters, many of which are not equipped to meet their unique needs (Matthew House, n.d). Often times refugee claimants are referred to a refugee-specific shelter that provides temporary accommodation along with help navigating the asylum process (Kissoon, 2010). These organizations and their frontline staff are tasked with helping this population secure affordable housing in the community. In Toronto, these organizations that assist refugees face additional obstacles as the housing market is in a precarious state. Since buying a house is unaffordable even for the average person in Toronto, more people are being forced to rent units for longer periods of time (Martin, 2017a). Consequently, Toronto's rental market has a very small vacancy rate, and rental costs for units are ever increasing (Martin, 2017a). Therefore, there is fierce competition for available and affordable units, putting refugee claimants in a disadvantaged situation. This evidently puts frontline workers (FLWs) in a difficult position to find adequate and available housing for refugee claimants.

\subsection{Research Focus}

This Major Research Paper (MRP) will explore the barriers that FLWs face when searching for housing for refugee claimants in Toronto. Toronto is the capital of Ontario, which is the top destination province for refugee claimants in the country (Government of Canada, 2017a). Furthermore, as it is the largest city in Canada and has the largest foreign-born 
population in the country, it was also the first city in Canada to declare itself a sanctuary city (Keung, 2013). Toronto is a fitting location to study the barriers to finding housing as it is currently facing a growing housing problem with limited availability of rental units and increasingly high cost of buying a home. Moreover, due to its historical role as a primary reception city for immigrants and refugees, Toronto has a significant and diverse range of services available for refugee claimants who are in need of assistance. This paper addresses the following research questions:

1) What is the process for finding housing for refugees in refugee shelters in Toronto?

2) What barriers do FLWs face when searching for housing?

3) How do FLWs navigate these barriers?

4) Do their work conditions affect how they perform their work?

5) What policy recommendations could be implemented to alleviate the barriers FLWs are facing?

My research interest is two-fold. By using the term "barriers", firstly, I am referring to the barriers that FLWs experience on behalf of their clients. Examples of such barriers include systemic barriers, as in standard rental policies which make it difficult for refugee claimants to qualify for apartments, in addition to financial barriers. Secondly, I will also consider barriers that FLWs experience in their workplace, which could impact the success of their work. These findings will allow me to illustrate a more detailed and nuanced picture of the challenges experienced by settlement workers on behalf of refugee claimants in order to formulate more effective policy recommendations to alleviate the barriers FLWs are facing in Toronto. Furthermore, these findings will be beneficial as it will fill the void in the literature regarding this topic. 


\subsection{Research Purpose}

I have chosen to interview FLWs instead of refugee claimants themselves, as this is an under-represented viewpoint in research. Not only is there little research on the important role of FLWs and their important contributions to the needs of refugee claimants, but there is also a lack of research on the topic of housing specifically related to refugee claimants. This paper will therefore be my contribution to this knowledge and it aims to fill in this knowledge gap. I believe that as FLWs have direct experience dealing with refugees in a number of capacities, including navigating the housing market, they will have important knowledge and experience, which could shed light on why refugee claimants have a difficult time finding housing in Toronto. Such research will be necessary as protecting and assisting this vulnerable population from further exploitation is crucial, especially at a time when resources for assisting newcomers are strained and the state of the housing market appears to be worsening. Moreover, dealing with this problem before it worsens will be critical in assuring the city's and province's resources are used as effectively as possible and planned pre-emptively to limit a potentially greater reliance on social assistance in the future.

\subsection{Definitions}

As this paper focuses on the experiences of both refugee claimants and FLWs, it is necessary to provide definitions of these important terms.

\subsubsection{Refugee Claimants}

This research project focuses solely on refugee claimants, rather than government sponsored or privately sponsored resettled refugees. Government and privately sponsored refugees are determined refugees while outside of Canada, by the United Nations High Commissioner for Refugees (UNHCR) or a designated referral organization, and are granted 
permanent residency once they arrive (Government of Canada, 2017b). Both groups receive financial and settlement assistance, either from the Government of Canada or their private sponsors, for approximately one year (Government of Canada, 2017c, Government of Canada, 2016a). However, refugee claimants, also referred to as asylum seekers, are not determined Convention refugees while they are outside of Canada. The International Organization for Migration (n.d.) provides the following definition of an asylum seeker:

A person who seeks safety from persecution or serious harm in a country other than his or her own and awaits a decision on the application for refugee status under relevant international and national instruments. In case of a negative decision, the person must leave the country and may be expelled, as may any non-national in an irregular or unlawful situation, unless permission to stay is provided on humanitarian or other related grounds.

Refugee claimants, or asylum seekers, must travel to Canada on their own, and must cover all the costs associated with migration and settlement on their own (Matthew House, n.d.). Upon arrival, they must make a claim for refugee status at a port of entry or inside Canada (Government of Canada, 2017d). Claims are heard by the Immigration and Refugee Board (IRB), an independent administrative tribunal, which "is responsible for making well-reasoned decisions on immigration and refugee matters, efficiently, fairly and in accordance with the law" (Immigration and Refugee Board of Canada [IRB], 2016a). During their hearing at the IRB, individuals must defend their claim for asylum by demonstrating that if they were to go back to their home country, they would face persecution. This is explained in Article 1 of the 1951 Convention Relating to the Status of Refugees, to which Canada is a signatory:

"For the purposes of the present Convention, the term "refugee" shall apply to any person who [...] owing to well-founded fear of being persecuted for reasons of race, religion, nationality, membership of a particular social group or political opinion, is outside the country of his nationality and is unable or, owing to such fear, is unwilling to avail himself of the protection of that country; or who, not having a nationality and being outside the country of his former habitual residence as a result of such events, is unable or, owing to such fear, is unwilling to return to it." (UNHCR, n.d., p. 14) 
Refugee claimants must re-tell their past experiences and the reasons that led them to leave their homes and also must provide evidence to substantiate their claims (IRB, 2016b). A Refugee Protection Division member takes this information into account and makes the decision on whether to grant or deny the individual refugee status (IRB, 2016b). If an individual is denied, they can apply to the Refugee Appeal Division (Government of Canada, 2016b). This paper considers the experiences of refugee claimants who have not yet had their hearing with the IRB, those who were granted refugee status, as well as those whose claims were denied and who are appealing the decision.

From the point of arrival and while waiting for their decision, refugee claims may seek shelter at a total of 62 shelters and community partners in Toronto that provide approximately 5,258 emergency and transitional housing beds (City of Toronto, n.d.; City of Toronto, 2017). While refugee claimants are able to stay at any of these shelters, there are approximately seven refugee specific shelters in Toronto (Kissoon, 2010). There are those that receive some government funding such as Sojourn House, and those that are faith-based charities such as FCJ Refugee Centre and Matthew House (Kissoon, 2010). Additionally, there are family shelters, such as Red Door Family Shelter, that also provide settlement services for refugee claimants (Kissoon, 2010). Refugee claimants typically exit these shelters by finding a rental unit with social assistance, secured with the help of an FLW (Kissoon, 2010).

\subsubsection{Frontline Workers}

By using the term FLWs, I am referring to people who work for an organization that directly serves refugees. The role of FLWs can change on a day to day basis, and FLWs across different organizations do not all have the same duties and responsibilities. The term FLW can also be used to refer to positions such as housing support workers and settlement workers. For 
the purposes of this research, however, I will solely be using the term FLW to mean those who work with refugee claimants.

As FLW is a broad term and can be applied to many different types of employment, it was a challenge finding literature that adequately describes the roles my participants take on in their employment. However, a few resources exist that describe the role of a housing support worker (HSW). Oudshoorn, Van Berkum and Michelucci (2016) assert in their article, "The Role of the Housing Support Worker", that there is a shortage of literature and no universal description of this role. They, therefore, analyzed job postings to create a proper definition, which they summarize:

"HSWs work alongside individuals to build trusting, therapeutic relationships that are centered on providing individualized, person driven, asset based, trauma informed support. Examples of support may include assistance in accessing community services and community integration, finding and maintaining housing, or acting in a role of advocacy when it is appropriate to do so. HSWs also work with people in areas of skill building, goal setting, and safety planning. Often a HSW is a "go to" person for support when problems arise, such as legal or financial concerns. Depending on individualized goals, HSWs may support those in which they are working alongside in areas of autonomy and self-determination." (p. 4)

This definition is a valuable tool for this research paper and is applied to describe a role all participants take on during their work. In order to clarify and contextualize the definition of the role with regards to this study, participants were also asked to describe their own role. This will be addressed in both the findings and analysis.

\section{CHAPTER 2: A REVIEW OF THE LITERATURE}

The following section will review the available literature on housing for refugee claimants and FLWs. Firstly, the current state of housing in Toronto and the competition for units that exists will be discussed. This will be followed by refugee claimants' needs and their 
access to services and social assistance in Ontario. Next, possible barriers refugee claimants face when attempting to access housing will be reviewed. Finally, the importance of the role that FLWs play, the difficulties they face working with this population, as well as the challenges they find in the workplace will be discussed.

\subsection{The State of Housing in Toronto}

A continuing trend in Canada is that newcomers continue to settle in its three largest cities; Toronto, Vancouver, and Montreal (Statistics Canada, 2005). In a study by Statistics Canada in 2005, they found that more than $60 \%$ of immigrants as well as $70 \%$ of recently arrived immigrants lived in these three cities (Statistics Canada, 2005). Toronto is the largest city in Canada with the largest foreign-born population, with $50 \%$ of residents being born outside of the country, and "where more than 150 languages are spoken every day" (The Canadian Magazine of Immigration, 2016; Ontario Immigration, 2016). Having such a diverse population and concentration of newcomers makes Toronto a sensible choice for the focus of this study.

While newcomers continue to settle in high numbers in the Toronto area, living costs in Toronto have been increasing exponentially. In December 2016, the Toronto Real Estate Board reported that the average monthly rental cost of a one-bedroom condo in the city was $\$ 1,776$ (as cited in CBC News, 2017). As housing prices soar, those that would be first-time home buyers in Toronto are reconsidering, with many choosing to rent instead for longer periods of time (McMahon, 2017). Additionally, the Canada Mortgage and Housing Corporation reports that the condo apartment vacancy rate in Toronto is $1 \%$, which is the lowest it has been in 7 years (as cited in Martin, 2017a). As more and more people continue to move to the Toronto area, and less and less units are available to rent, rental prices have surged and significant competition exists for available units (McMahon, 2017). 
Up until very recently, Toronto was experiencing another issue with regards to rent increases for people already occupying their own accommodation. Commonly known as the "1991 loophole", this regulation was put forth in 1997 by the provincial government through the Tenant Protection Act (Bill 96). This Act kept intact the rent control guideline that permitted a maximum rent increase for buildings erected or units occupied before 1991, while removing rent control on buildings built after that year, providing the landlord supplies the tenant with a Notice of Rent Increase (Leach, 1996). Therefore, if a tenant occupied a unit in a building that was constructed after 1991, landlords were able to increase rent prices annually at any time and by any amount. While the legislation was put in place in order to motivate more rental developments, it resulted in sharp, unexpected rent increases for tenants, and spurred significant developments of condominiums, rather than the crucially needed apartment buildings (Martin, 2017b). However, on April 20th 2017, the provincial government declared that they would be extending rent control to all units, regardless of when it was built unless a Notice of Rent Increase had already been provided to the tenant before the aforementioned date (Landlord and Tenant Board, 2017). While this comes as a sigh of relief to Toronto renters, rent continues to remain quite high. Landlords are still allowed to increase the price of units by any amount between tenants (Sienkiewicz, 2017). Additionally, rental bidding wars are also allowed, and are common in Toronto (Sienkiewicz, 2017; DaSilva, 2016). Applicants can offer to pay more than the stated monthly rent in order to increase their chances of securing the unit (Sienkiewicz, 2017). Furthermore, while landlords are legally only allowed to ask for first and last month of rent, applicants can, and do, offer to pay for additional months to beat the competition (DaSilva, 2016). Evidently, the demand for housing in Toronto has produced a climate of competition amongst desperate prospective tenants and has allowed for a significant shift in power to the 
hands of landlords who not only exercise a large degree of control over rental prices despite policy initiatives to limit increases, but also take advantage of the high demand and allow bidding wars to ensue.

Moreover, a major concern in the city is the shortage of social housing. The Toronto Community Housing, the largest social housing provider in Canada, which provides homes for low and moderate-income households, is unable to keep up with the large demand for public housing (Toronto Community Housing, n.d.; Brown, 2016). With a waiting list of over 97,000 households, families are now having to wait almost ten years to receive social housing (Brown, 2016). Additionally, due to lack of funds for repairs by the provincial government, 600 units are planned to be shut down this year, in addition to 400 units in 2018 (Pagliaro, 2017). The Toronto Community Housing must relocate individuals and families affected by the closures, putting additional pressure on the already long wait list (Pagliaro, 2017).

\subsection{Accessing Services and Social Assistance}

A group of people that enter this competition for accommodation are refugee claimants. Toronto is home to approximately 5,000 refugee claimants per year, most of whom often live in poverty and are susceptible to homelessness (Kissoon, 2010). Refugees experience serious trauma and discrimination in their homeland, which consequently forces them to make the decision to flee. This trauma can result from war, violence, torture, living in refugee camps, forced migration, leaving behind one's possessions, losing or separated from family members, among many other hardships (Kirmayer et al., 2011). In order to arrive to Canada, refugee claimants might have sold their property and spent a significant amount in order to fund their way, and therefore may experience a reversal in social status and have limited funds when they arrive in Canada (Kissoon, 2010). 
Refugee claimants who are in need of funds can apply to Ontario Works in order to receive social assistance (Government of Ontario, n.d.). This is the same system in place for Canadian citizens who are applying for social assistance. In order to be eligible, the individual or family must live in Ontario, be currently in need of funds for food and shelter, and must demonstrate that they are making efforts to find employment (Government of Ontario, n.d.). In an application, one's number of family members, income, assets, and housing costs must be stated. The Government of Ontario assesses applications based on these factors to decide if the individual or family is eligible (Government of Ontario, n.d.). As of September 30th 2016, an individual will receive $\$ 330$ for basic needs, as well as $\$ 376$ for shelter, for a total of $\$ 706$ per month (Income Security Advocacy Centre, 2016). As this maximum monthly social assistance is notably lower than the average cost of a rental unit in Toronto, it significantly limits the range of rental options that refugee claimants can afford. Refugee claimants are therefore notably at risk of living in poverty and without means to find adequate accommodations (Sherrell, D'Addario \& Hiebert, 2007).

\subsection{Barriers in Access to Housing}

Refugee claimants face many obstacles in regards to acquiring housing from their very arrival on Canadian land. Prior to arriving, their experience of having lived through forced migration and the trauma they may have experienced or witnessed during their lifetime contribute to a host of issues, from mental health to extreme economic insecurity, all of which lead of social inequality (Kirmayer et al., 2011). Further disadvantages appear during their arrival and initial integration, such as feelings of isolation, due to their separation from old social networks, as well as stress caused by having to adapt quickly to completely new surroundings and a different society. In many cases, lack of language skills can be a major stressor in all facets 
of life in the host country, causing further social inequality (Agic, McKenzie, Tuck \& Antwi, 2016). Some of these vulnerabilities become heightened and compounded while searching for housing by factors such as lack of knowledge of the housing and rental market, the realization of their economic disadvantages, lack of language skills, as well as racism and discrimination by landlords and real estate agents, which tends to affect visible minorities more than white Canadians and white immigrants (Teixeira, 2008). While it is possible that all newcomer groups experience this, there have been a number of articles that highlight that refugee claimants have "heightened vulnerabilities" as, to add to all the other stressors, they have a lack of status and can often end up being the most neglected group when it comes to government aid (Brigham, Baillie Abidi, Tastsoglou \& Lange, 2015, p. 29).

This is exemplified in the work of Murdie (2005), who focused on the housing differences and outcomes between sponsored refugees and refugee claimants in Toronto. His research demonstrated that refugee claimants had a much more difficult time finding housing compared to those who were sponsored. On average, sponsored refugees found housing within a month, whereas refugee claimants took more than 7 months (Murdie, 2005). Through his interviews, he found that:

"[t]he most important barriers in the search were lack of a job (20 mentions), low income (15), being on social assistance (14) and large family size (10). Race, cultural background, language and religion were mentioned less frequently ( 3 to 5 mentions) perhaps because of the overwhelming importance of economic factors." (p. 93)

However, Murdie (2005) states that “...visible minority newcomers may have never experienced discrimination based on race before and may not fully recognise the subtleties of this form of discrimination in Toronto's housing market" (p. 93). He mentions that housing workers were crucial to many refugee claimant participants in order to bypass barriers to access housing, such as language and the need for a co-signer (Murdie, 2005). Murdie's article alludes to possible 
results and responses which could be discovered by further exploring the experience of FLWs, suggesting that there is high potential that FLWs may have greater insight in noticing different aspects of discrimination.

In order to investigate why these differences exist for different groups, the Centre for Equality Rights in Accommodation (CERA) wrote a report in 2009 entitled “'Sorry, it's rented.'Measuring Discrimination in Toronto's Rental Housing Market”. CERA sought to investigate the extent to which housing discrimination exists in Toronto and how it varies across different segments of vulnerable members of society. They claim that those who report housing discrimination often "experience [a] range from blatant, intentional discrimination to more subtle, systemic discrimination where seemingly neutral rental policies or practices lead to discriminatory outcomes" (CERA, 2009, p. 1). In the study, participants experienced intentional and explicit discrimination, which manifested as direct comments made about their undesirability on the basis of their race, marital status, family size, etc (CERA, 2009). Systemic discrimination, while not as blatant, also created numerous obstacles for the groups studied. For example, requirements like credit checks, rental histories, or mandatory income levels, directly excludes groups like newcomers (CERA, 2009).

While intentional, more blatant discrimination typically occurs in more private spaces, such as face to face interactions or phone calls, there is a grey area of discrimination that is inherent in the current housing market. When landlords and tenants look to rent available rooms, they can use certain vocabulary and keywords to define their ideal candidates in their advertisements. This results in the exclusion of certain potential applicants. This exclusion can be based on certain reasonable preferences, such as smoking habits and possession of pets. However, a quick look through advertisements on classified websites such as Kijiji and Craigslist 
show that these preferences escalate to even include gender, language, religious-based or ethnic requirements. The Ontario Human Rights Code denounces any discrimination on the basis of sex, age, gender, ethnic or religious background (Ontario Human Rights Commission, 2009). Yet, certain measures exist to allow the advertiser to post preferences such as gender in postings for shared accommodations. In such cases, a young female student or professional may exclusively request inquiries from interested young female students or professionals. While such preferences could appear seemingly reasonable to the advertiser, these posts discriminate on many different levels (age, gender, social status), exemplifying how systemic and intentional discrimination appear disguised and unchecked. For example, highlighting employment as a preferred characteristic would deter or exclude some refugee claimants. One main reason is that while some refugee claimants are qualified to apply for work permits, processing times for permits can be long. The Government of Canada website states that as of May 2017, the processing time of a work permit for a refugee claimant takes 48 days if applying online and 106 days if applying by mail (Government of Canada, 2017e). In addition to this lengthy waiting period, refugee claimants must learn how to navigate finding a job in a new country, which takes significant time, and would make it difficult for refugee claimants to fulfill the requirement of being employed.

Another dimension to consider is that as advertisements are now more common online on free classified websites, discriminatory posts are more difficult to track, and reporting this type of behaviour rests solely on the person experiencing the discrimination (Boesveld, 2011). Unfortunately, most do not report experiencing discrimination when searching for accommodation - they understandably move on to the next advertised room as their priority is to secure housing (CERA, 2009). Due to their economic insecurity and lack of a strong social 
network, many do not have the funds or resources to legally challenge this discrimination, and many experience discrimination without even being aware that it is happening (CERA, 2009). Moreover, having a precarious legal status may deter them from confronting this discrimination.

Modern forms of advertisements also intersect with a shift to new mediums of communication, which tend to increase the potential for discrimination. Inquiries for rental units are primarily done through online search engines, and then text messaging, emails and phone calls are the primary means of first contact with the landlord (Massey \& Lundy, 2001). Refugee claimants, then, may put themselves at risk of discrimination on the basis of written proficiency in English (or French) or by having their accent heard before actually meeting landlords or property managers in person.

Accents are a recurring theme in the literature because they are seen to act as an indicator of ethnic background, which can lead to discrimination (Munro, 2003; Creese, 2010; Derwing \& Waugh, 2010). Munro (2003) states that a significant potential reaction to hearing an accent is that "the prejudices one holds against a particular group of people may be activated when one hears speech patterns associated with that group" (p. 13). Munro (2003) describes this behaviour as accent stereotyping, which manifests as discrimination directed at certain groups or individuals from other countries. Accent discrimination could have negative effects for newcomers seeking accommodation, whether on the phone or in person, and could also affect them in other facets of their lives such as education and employment, where having an accent may put them at a disadvantage (CERA, 2009; Creese, 2010). Additionally, it is important to consider that even FLWs could have come to Toronto as immigrants or refugees and may have an accent, which could potentially hinder their success in finding accommodation for their 
clients. Yet, they still may be able to better pinpoint an occurrence of discrimination than refugee claimants.

Refugee claimants face additional barriers due to their "precarious legal status" (Sherrell, D'Addario \& Hiebert, 2007, p. 70). As they do not have permanent residency, it has been reported that landlords can hold negative views of refugee claimants, and refugee claimants can face exploitation, and poor housing conditions (Sherrell, D'Addario \& Hiebert, 2007). While Canada is known to be a welcoming country to refugees, statistics show that this is not true for the whole population. A 2016 survey conducted by the Federal government on immigration attitudes found that $40 \%$ of 1,598 respondents believed that Canada accepted the right number of refugees, while $30 \%$ answered that numbers were too high. Only $46 \%$ responded that refugees "have a positive impact on the Canadian economy" (Levitz, 2017). These statistics demonstrate that there is a considerable minority of Canadians that hold negative and misinformed views of refugees. Hence, there is a possibility that some landlords hold these negative perceptions of refugee claimants, which can put refugee claimants at risk of discrimination when seeking housing.

Statistics pertaining to the housing market also demonstrate how discrimination can heighten and subside at different times. Authors Novac, Darden, Hulchanski and Seguin (2002) who prepared the report entitled, "Housing Discrimination in Canada: The State of Knowledge", present an argument that could further explain how housing discrimination functions in Toronto. They state that when vacancy rates of units are very low (under 1\%), the demand is high for low and medium cost accommodation, and therefore landlords are less likely to treat all potential renters equally (Novak, Darden, Hulchanski \& Seguin, 2002). However, when vacancy rates are high (over 6\%), demand for units is low, and therefore landlords will be more inclined to rent to 
applicants with low incomes, who receive social assistance, as well as newcomers (Novak et al., 2002). Therefore, when competition is high for units, landlords are more likely to pick and choose their tenants to meet their personal preferences (Novak et al., 2002).

\subsection{Frontline Workers}

More general studies have been conducted to investigate why housing discrimination exists in Toronto and across different segments of society, but there have not been focused studies on those who are tasked to help refugee claimants in their search. However, some important research has been done on the effect which an FLW's work can have on refugee claimants, which is a critical consideration for this paper.

Brigham, Baillie Abidi, Tastsoglou, and Lange’s (2015) article “Informal Adult Learning and Emotion Work of Service Providers for Refugee Claimants" provides an approach and focus that is similar to this research paper. The authors interviewed service providers who work with refugee claimants and discussed how they engage in very emotional work, as " $[\mathrm{t}]$ he experience of work is saturated with feeling" (Brigham et al., 2015, p. 34). Participants in their study consistently exemplified through their interviews that "there is an intensity of emotions involved in providing service for persons who are fleeing persecution” (Brigham et al., 2015, p. 34). They expressed frustration "over the lack of options they have to support refugee claimants in their communities and the challenges of witnessing the aftermath of a negative refugee board decision" (Brigham et al., 2015, p. 36). They also noted that their work affects their personal lives after the work day is completed (Brigham et al., 2015).

In a similar study, Robinson (2014) examined the roles of FLWs working in refugeefocused non-government organizations in both Australia and the United Kingdom. FLWs came from a wide range of employment, which included community workers, nurses, social workers, 
and a general practitioner. Robinson (2014) found that the 30 participants were often not prepared or supported by their workplaces to cope with the high demands of the work, which often resulted in workplace stress. Participants reported feeling powerless and experienced vicarious trauma when working with their service users (Robinson, 2014). A recurring theme throughout the interviews in Robinson's study was that participants had "little or no access to supervision" which had a seriously negative effect on the workforce. Researching the barriers that FLWs face when attempting to secure housing may provide a wealth of information regarding the struggle refugee claimants face during their initial settlement experiences. Furthermore, this research paper further explores the idea of how working with this vulnerable population affects FLWs after their workday is completed.

\section{CHAPTER 3: THEORETICAL FRAMEWORK}

This study will apply the theory of Anti-Oppressive Practice (AOP) in order to understand and analyse how FLWs, who take on the role of a social worker, navigate barriers and advocate on behalf of their clients. This chapter will provide a review of the theory and apply it to the context of this paper, which will be used to analyse the findings of this research.

\subsection{Understanding Anti-Oppressive Practice}

AOP is a multidisciplinary theoretical framework that incorporates aspects of "sociology, psychology, history, philosophy and politics" (Burke \& Harrison, 1998). AOP is social justice oriented and is entrenched in the field of social work (Baines, 2011). It is aimed at "fundamentally transforming the political, economic, social and cultural factors underlying and generating inequality and injustice" (Baines, p. 2, 2011).

Dominelli (1998) defines AOP as: 
... a form of social work practice, which addresses social divisions and structural inequalities in the work that is done with 'clients' (users) or workers. Anti-oppressive practice aims to provide more appropriate and sensitive services by responding to people's needs regardless of their social status. Anti-oppressive practice embodies a person-centered philosophy, an egalitarian value system concerned with reducing the deleterious effects of structural inequalities upon people's lives; a methodology focusing on process and outcome; and a way of structural social relationships between individuals that aims to empower service users by reducing the negative effects of hierarchy in their immediate interaction and the work they do (p. 6).

AOP assumes that society is typically oppressive, which causes social problems and social hierarchies (Danso, 2009). Burke and Harrison (1998) succinctly define the driving force of AOP as "the act of challenging inequalities" (p. 133).

Baines (2011), who specializes in AOP from a frontline social work perspective, states that inequalities and oppression are produced through social relationships. These can be macro level social relations, such as social structures and social processes, and forces in society such as capitalism and government institutions. These social relations can also be micro level, such as “social norms, everyday practices, workplace specific policies and processes, values, identities, and so-called common sense" (Baines, p. 4, 2011). Baines (2011) stresses how these relations are all operated by people, and are therefore not static - they can be questioned and changed. Macro and micro social relations perpetuate notions of both inequality and inferiority through "ideas, values, and processes" (Baines, 2011, p. 4). These oppressions, such as race, gender, sexual orientation, ability and class, intertwine and overlap with one another, depending on how they are constructed in these micro and macro social relations (Baines, 2011). Therefore, problems and circumstances that clients face are not only due to their individual choices; there are social, political, cultural and economic factors at play that work against them, which they often do not have control over (Baines, 2011). AOP seeks to aid individuals with their needs or challenges, in addition to "challenging and transforming those forces within society that benefit from and 
perpetuate inequity and oppression" (Baines, p. 4, 2011). It is important, however, that clients are not only construed as victims. They must be seen as active agents and be empowered to challenge these oppressions themselves as well, and must have their voices heard in all discussions (Baines, 2011).

Baines (2011) defines how social workers incorporate AOP into their work:

Broadly speaking, anti-oppressive social workers try to provide service to people seeking it, but also they help clients, communities, and themselves to understand that their problems are linked to social inequality - to understand why they are oppressed and how to fight for change. (p. 4)

An additional component of AOP which social workers need to apply is cultural competence. As cultural differences can be used to exclude certain groups, having cultural competence helps with the provision of appropriate and sensitive services. It enables "practitioners to appreciate diversity better and work towards dismantling attitudes and practices that construct difference as a problem" (Danso, 2009).

It should also be considered that the field of social work itself often encounters institutional inequalities; this can occur between workers and clients, workers and their agencies, and agencies and the state. These power imbalances in the social work setting, while not inherently oppressive, provide opportunities for oppressive practices to emerge (Strier, 2007; Sakamoto \& Pitner, 2005). Social workers must be aware of subtle dynamics of how oppression operates and affects clients, in order to not reinforce oppression themselves (Strier, p. 866, 2007). They must also be critical of their privileged status in contrast to their clients (Danso, 2009). Social workers, therefore, must reflect on their "position within social structures" and consider how their own social identity affects how they perform their role (Danso, p. 542, 2009; Burke \& Harrison, 1998). 
As the focus of this paper is primarily the FLWs themselves, it is important to also note that the adoption of AOP can be quite challenging as there are no clear guidelines on how to effectively use the practice in case by case service provision to individuals and families (Sakamoto \& Pitner, 2005). Other criticisms of the practice contend that the main purpose of AOP itself "can be seen as discouragingly lofty, especially for practitioners who may already have too much on their plate. This could ultimately lead to apathy on the part of the practitioner" (Sakamoto \& Pitner, p. 438, 2005).

\subsection{Applying Anti-Oppressive Practice to Canada's Refugee System}

The literature on refugee claimants in Canada examines their experience in the context of both macro and micro social relations, which both create structural inequalities and put the claimants at risk of varying forms of discrimination. Broadly speaking, macro social relations define the socio-political landscape which refugee claimants navigate in Canada. From the onset, the very nature of the relationship between the state and refugee claimants is a notably hierarchal one. Canada holds a privileged status as a developed country, with a strong economy and high standards of living; this is in contrast to developing countries from which large populations of persecuted groups emigrate, and which have much lower relative wealth and living standards. While being a signatory to the 1951 Convention on Relating to the Status of Refugees requires Canada to provide temporary asylum to persecuted individuals, it does not require Canada to accept all claimants (Kissoon, 2010). In this regard, the state wields an unfairly large degree of power over refugee claimants, who are put into precarious and vulnerable positions and whose claim decision is entirely dependent on the state. Further, Canada faces fewer risks by allowing refugees into the country in comparison to the refugee claimants themselves, who in addition to making great sacrifices to travel to Canada, also risk being denied status and having to return to 
the persecution from which they were trying to escape in their home countries. A further imbalance is that refugee claimants must navigate a very complex asylum process, riddled with legal terms and processes that, given the time they have to prepare themselves, could never be fully understood without the help of someone who specializes in the asylum process itself. This puts refugee claimants at a serious disadvantage. Such conditions define the macro social relations pertaining to the topic of refugee claimants and illustrate the grave inequality that exists in this relationship.

During the period in which they make their claim and await the government's decision, refugee claimants must also manage to find a way to survive in Canada. More specifically, with regards to the topic of this paper, refugee claimants must find accommodations on their own - as opposed to sponsored refugees. This is crucial as it puts refugee claimants in an even more precarious and powerless state and requires them to enter into micro social relations, which expose them to varying forms and degrees of systemic and intentional discrimination through rental policies and by interactions with prospective landlords or roommates.

The findings of this study will demonstrate how the role of FLWs naturally adopt the AOP approach when working with their clients to address the systemic and intentional discrimination existing within the housing market. This study will also highlight what barriers continue to exist despite the adoption of the AOP approach.

\section{CHAPTER 4: RESEARCH METHODS}

This section describes how the research was conducted. It discusses my positionality, participant selection, data collection, and the limitations of the project. 


\subsection{Researcher Self Disclosure}

In order to understand my reasoning for researching this topic, it is necessary to disclose my positionality. Over the past two years, I have been volunteering at Matthew House Ottawa and Matthew House Toronto. Both of these are refugee specific shelters that provide temporary accommodation, assistance with making a refugee claim, and settlement assistance to refugee claimants. Matthew House also aims to provide community and a sense of family and belonging to their residents. My time at these organizations has given me valuable knowledge of the settlement experiences of refugee claimants in Canada. My roles have included duties such as helping with the overall maintenance of the household infrastructure, providing orientation sessions for recently arrived clients as well as new volunteers, and assisting with work permit applications. However, the most challenging role that I occasionally perform is attempting to find housing for clients. Through searching advertisements on websites and calling landlords about their available units, I have experienced systemic and blatant discrimination that is directed at our clients. I have noticed that refugee claimants not only have difficulties being able to afford living in Toronto, but their precarious status, as well as the stigma associated with them, can deter landlords or potential roommates from choosing them as renters. This experience has therefore provided me with somewhat of an "insider perspective", subsequently shaping my interest in pursuing this topic.

Additionally, I myself moved to Toronto and experienced what it was like to try to find accommodation in the city. It was extremely difficult to find units that fell within my price range and that were in a reasonable distance from Ryerson University - the location of my Masters program. I sent messages through Kijiji and Craigslist for those apartments I could find and often did not hear back or was told that the unit was already gone. This is evidence of the limited 
available units and the speed at which they are taken. Many of the rooms could barely fit both a bed and a desk, and did not have windows. One unit that I viewed and put in an application for was rejected, as I was outbid by someone else. From September 2016 to June 2017, I lived with a roommate in a one-bedroom apartment, in the living room, with curtains and room dividers, and no door. I highlight my experience as I believe it sheds light on how difficult it must be for refugee claimants to find accommodation if those with citizenship, speak the native language fluently, and have white skin have trouble as well.

\subsection{Research Design}

I have chosen to do qualitative research for this MRP. I interviewed FLWs in Toronto as I believe they have a clear understanding of barriers faced in housing, as there is a high number of refugee claimants in Toronto in addition to an unstable rental market. Furthermore, I believe FLW's are able to articulate certain aspects of these housing challenges as they engage in apartment-hunting often. As this is an understudied profession, I believe it is important to give these workers a platform to express their experiences. Interviews were semi-structured, and approximately 25 questions were asked during the meetings with participants. Questions were a mix of closed and open-ended, and participants could focus on what they thought was important to bring up. Questions focused on their experiences on finding housing in Toronto, as well as their work conditions and experience at their respective organizations. Interview questions were followed by probe questions when clarification and/or more details were desired.

\subsection{Participant Selection and Recruitment}

After receiving approval for this project from Ryerson University's Research Ethics Board, I began recruiting participants. I went to multiple refugee-specific shelters in Toronto, where I gave my recruitment poster to the front desk or posted it on their community boards. The 
recruitment poster briefly stated my research interest, the inclusion criteria of who could participate, the length of time an interview would be, and my contact information. The poster stated that all inquiries would remain confidential. Participants were encouraged to contact me via their personal email, as opposed to their work email, in order to keep their identity confidential. The inclusion criteria for participants were: FLWs or housing support workers that work at refugee-specific shelters, that help refugee claimants find housing in Toronto, and that have a minimum of 1.5 years experience in this field of employment. The amount of 1.5 years experience was chosen in order to widen my inclusion criteria of people who could participate in the study. As there are approximately 6 refugee-specific shelters in Toronto, and therefore a limited number of FLWs that work at these organizations, I set my expectations low in regards to how many people would be interested in participating. Four participants from four different refugee specific shelters contacted me after seeing the recruitment flyer at their place of work.

Once interested participants contacted me via email, I sent them the consent form. This document summarized the purpose of my research, what participation entails, the participant's rights, and any potential risks involved. I sent this document via email prior to meeting in order for them to have a clear understanding of my project, as well as to permit them to take the time to decide if they still wanted to participate and to give them the opportunity to ask any questions they may have. After receiving their consent and confirming their desire to participate we agreed on a time and place to meet. Interviews were conducted solely by myself.

\subsection{Data Collection}

Before commencing interviews, I went over the consent form with my participants and encouraged them to ask any questions they may have. Participants were reminded that they could skip any questions, or withdraw completely from the study at any time. They were informed that 
all information recorded would remain confidential, that pseudonyms would be used in the paper, and that their place of work would not be stated. As stated in the consent form, participants were informed that they could review any direct quotes or information to ensure their identity remained confidential. I stated that myself, as well as my supervisor Dr. Idil Atak, would ensure that information that can potentially identify participants would be de-identified in the MRP. Interviews ranged from 45 minutes to 1 hour in length. They took place in various locations where participants felt comfortable and that was convenient for them. Locations included the Student Learning Centre at Ryerson University and public libraries.

Before interviews commenced, participants were given a hard copy of the consent form to keep, and they signed a copy of the consent form, which I kept. Signed copies of consent forms were stored in my own personal locked desk. Interviews were audio-recorded solely by myself, using a recording device provided by Ryerson University. Once interviews were completed, this data was encoded and encrypted, and stored on my personal laptop. Data was then deleted off of the audio-recording device. The interviews were transcribed by myself. Names of participants were coded and kept separately from one another. All data will be stored for 1 year after my MRP is successfully defended, and then destroyed.

The research questions previously mentioned prompted interview questions such as: Can you describe the process of finding a house for refugee claimants? When calling landlords or apartment complexes, do you inform them that you are calling on behalf of a refugee/refugee centre? When/If you do inform them of this, what type of reactions do you receive? Does someone from your organization accompany the client to view the unit, or does the client go alone? Can you explain why this takes place? How many people in your organization have the 
same role as you? How do you feel about this number? Do you feel as though you have enough support from your organization to successfully do your job?

\subsection{Data Analysis}

In order to critically engage with the content of my participants' interviews, transcripts were printed off, and read multiple times to get a proper understanding of important aspects. I analysed my transcripts and pulled out recurring themes in participants responses that helped to answer my research questions. I also highlighted aspects that participants felt were important and necessary to mention.

\subsection{Limitations}

A few limitations exist in this study which are necessary to highlight. Firstly, as there was limited time to recruit participants, only four people participated in this study. This paper therefore does not aim to make generalizations about all FLWs who work at refugee shelters. However, it provides an in-depth look at the experiences of these particular FLWs and the challenges they face in Toronto. Participants responses also confirm many of my own observations I have witnessed and experienced as a volunteer at Matthew House.

Furthermore, while participants provided significant and relevant information during their interviews, there are certain limitations to some of their answers. As my interviews included some personal and work-related questions, it is possible some participants hesitated to provide fully honest and in-depth responses to some questions. They may have been especially reluctant to provide certain information regarding their employment and work conditions due to the concern that their employers could discover such information. Ultimately, it is difficult to know how much information was withheld because of such concerns. 
Finally, due to the limited amount of refugee shelters in Toronto, and hence the limited number of potential participants that could be recruited, limited details can be shared about the characteristics of the participants that were interviewed. This is necessary in order to protect their confidentiality as these details could be used to identify them.

\section{CHAPTER 5: FINDINGS}

This chapter identifies recurring themes found in the interviews and highlights significant experiences discussed by the participants during their interviews. Firstly, characteristics of the participants will be stated to provide some general information on their background in the field. This will be followed by a summary of how participants described their roles within their organizations and their responses surrounding how they find accommodation in Toronto for their clients. Next, the barriers that participants face when searching for housing for their clients will be discussed. This is followed by an analysis of how participants believe the overall housing search affects their clients. Participants opinions on their workplace and work conditions will ensue. Finally, suggestions on policy and regulation changes to the housing market put forward by the participants will be relayed.

\subsection{Participant Characteristics}

All participants work with refugee claimants in searching for housing; however, their day to day tasks vary and no one participant has the exact same duties as another. Some are front line staff or housing support workers, and some are managers and supervisors. There were 3 males and 1 female that participated in the research. The number of years working with refugee claimants in this capacity ranges from 2 years to over 15 years. Some were born and raised in Canada, and some immigrated to Canada. 


\subsection{Defining Participants Roles in Refugee Shelters}

As literature is scant on the roles of people who work in refugee shelters, this section will highlight how participants define their roles in addition to their day to day tasks. The shelters where the participants are employed do not function in a singular, set way. The types of clients they serve vary, as some shelters specialize in families, some focus on single individuals, and some shelters offer help to a mix of both. Length of maximum stay for refugee claimants at the shelters which the participants work at vary, from 3 months to 1 year. Some shelters are converted homes or apartments where clients can receive a bed in a shared room with other refugees, some can receive private units, and some shelters offer both types of accommodations depending on the client's needs.

Participant \#1 shared that, at his organization, he assists clients with both their refugee claims procedures and their settlement in Toronto. This involves helping them to feel comfortable in the community and supporting them in finding accommodation. When asked to describe his role, he summarized: “...[J]ust taking them through the entire process of entering the country, getting their basic needs in place, and helping them to settle in the community on their own". Participant \#2 elaborated that refugee shelters help in all aspects of their clients' settlement:

[W] help them acquire legal aid, find a lawyer, fill out paperwork, apply for work permits, go to English as a Second Language classes, we help them look for apartments, houses, rooms, whatever it may be. We just try and help them with everything possible while they're staying with us.

Participant \#3's organization partners their workers with specific clients in order to help them with all of their settlement needs and to build a strong companionship. In a broader sense, he shared that, “... you're walking with people through the entire process”. More specifically, though, he also provides housing services at a walk-in service at his organization. 
Participant \#4 shared on the role of her organization in the context of refugee claimants:

The population has gone through a tremendous trauma. And they're in Canada and they're in safety, however they're still dealing with that trauma from their country. [...] All the work we are doing is helping them to stabilize, through counselling, through, some might need medication and things like that. Helping them to set up a little bit before they move into permanent housing.

She also discussed that her organization takes in many unaccompanied refugee minors, those under the age of 18 that arrive to Canada without any family members. According to her, members of the organization become foster parents and help them learn life skills to be able to thrive in the community: "Even just preparing your food, self-care, time management, banking, money management... and how to navigate the most difficult and complicated immigration program here in Canada."

As can be seen, all participants help their clients extensively throughout both their refugee claimant process in addition to their settlement in Toronto. An important aspect of this settlement is acquiring housing.

\subsection{Finding Accommodation in Toronto for Refugee Claimants}

When asked about how they find accommodation for clients, Participant \#1 discussed how he begins by assessing his clients' needs. When clients are prepared to enter the community, the FLW and client decide together on what kind of housing to look for, if the client will live alone or with roommates, what kind of budget the client will have, and what areas of the city to look at. Similarly, Participant \#4's organization runs workshops in which they educate their clients on the housing market, how to look for housing, how to approach landlords, and how to budget.

All participants turn to the internet in order to find listings of available accommodations in the city. Websites that were stated in interviews included Kijiji, Craigslist, View It, and 
Padmapper. Participant \#3 expressed how he also reaches out to community relationships and networks for particularly difficult housing situations, such as large families. Participant \#4 discussed how she keeps a list of landlords that her organization has worked with in the past, and contacts them often in order to maintain a relationship. This is done in order to hopefully be able to contact these landlords when another client is in need of housing. She explained that she looks for ads anywhere possible, including newspapers, magazines, community centres and bus shelters. She explains: "So we have to use so many resources, we have to become very very creative in terms of when we are looking. You look everywhere." While it seems that there are an abundance of ways to find accommodation, all participants expressed frustration in fulfilling this task. Expressed by Participant \#3: “Regardless (of how you search), it's just like you're spitfiring. It's like a shotgun approach. You have to put a lot of leg work into something and then hopefully you'll find it."

When asked about who makes the telephone call to a landlord to inquire about a unit, answers varied. Participants \#1 and \#2 shared that they very often call on behalf of their clients. Participant \#2 finds that when clients do make the first call, they often lose their confidence as landlords can be very aggressive towards them. Participant \#1 said that his organization calls on behalf of clients as they may lack awareness of rules and laws surrounding the renting of units. He said: "We speak on their behalf. One of the main functions that we execute is advocacy for them. We are the front gate. Although the interest is theirs, we represent their interest to the landlord." They both, however, do encourage clients to search on their own and to reach out to friends and communities. Participants \#3 and \#4 shared that their organizations have a collaborative approach where both the client and the workers will contact landlords. This can vary, though, depending on their client's English-speaking level and their level of comfort. 
Participants were then asked what they say when calling landlords, and if they directly state that they are calling on behalf of a refugee claimant. Participant \#2 said that calling landlords can be awkward, as landlords assume that he is calling on behalf of himself and begin to "interrogate" him about whether he is employed, ask about his credit score, and ask how many people want to move in. He said:

Either way I kind of just pause the landlord and tell them I'm actually calling on behalf of a friend of mine. I'll say a friend, I stay away from client. I have to lie a little. [...] I just say they're in school right now, they're new to the country and I'm just helping them out. And if the landlord continues I kind of explain their situation, like they can afford it. Instead of saying welfare I say they receive government support as a newcomer. So that way they might think that they're a sponsored refugee rather than just a refugee on welfare. So there are small techniques I use.

Likewise, Participant \#3 also strays away from directly stating that he is calling on behalf of a refugee claimant or from a settlement agency, and states he is calling on behalf of a friend. Participant \#4 does state that she is calling on behalf of her client, but uses the term "newcomer" instead of refugee during the initial call. When landlords press for details, she states: "I'm calling because this person is fairly new, doesn't speak a lot of English, so we are going to be working together." She said that some landlords will be understanding, but some can be extremely uncooperative and press for many details about her position. They also ask to speak directly with the client, whom she has prepared in advance on how to respond. Participant \#1 is the only person who directly states that he is calling on behalf of a refugee claimant. He explained: First of all, if I don't tell them, I'm lying. And number 2, I'm wasting my own time. Because if the person doesn't want to rent to this person simply because he's a refugee claimant, they should refuse them right now so I stop this waste of time. If I don't tell them and I go prepare the papers, and I submit a lot of documents, and in the end they're going to say no, the loser is just us.

Participants were asked if they accompany their clients to viewings of units. Participant \#3's clients decide if they would like him to attend, and Participant \#1 does attend if possible. 
They both stated that this is done as it can be comforting to have someone who is aware of laws and regulations, somebody that knows what questions to ask, as well as having someone with strong English skills or that can translate. Participant \#2 attends very few viewings as his organization does not have the capacity due to limited funds and staff. However, for special circumstances he will "go and advocate for them." Participant \#4's organization always accompanies the client, as it can be intimidating for refugee claimants to go by themselves and ask landlords important questions. She explained that the person who accompanies them points out any problems in the unit to the landlord and asks them to be fixed before clients will move in.

All participants said that it takes approximately 3 months in order to find accommodation for clients. Participants \#1, \#2 and \#3 all agreed that as it is taking much longer to find housing for clients in the city, their organizations cannot serve as many people as they have in the past.

\subsection{Barriers to Accessing Housing}

This section will address the multiple barriers and challenges that participants face when searching for housing on behalf of their clients.

\subsubsection{Lack of Affordable Housing}

The most blatant barrier to housing for refugee claimants is that rental prices are too expensive for their budget. Participant \#1 highlighted how "housing just became crazy in the city" and how rental costs have skyrocketed. Participant \#1 and \#2 emphasized that the maximum amount paid to clients per month from Ontario Works is completely out of sync with average prices for units in the city. Participant \#1 said that while welfare increases slightly each year, it does not match inflation and thus the increase in social assistance is ultimately insignificant. 
Participants also highlighted the lack of subsidized housing in the city. Participants \#1 and \#4 expressed frustration that the waiting list for subsidized housing is so long and that applicants wait approximately 10 years to finally receive housing. Participant \#4 explained that many give up waiting to be contacted for social housing; however, "[ $\mathrm{t}]$ here are people who will wait, who are in need. Who might not be able to get employment, not because they don't want to work, maybe because of all kinds of challenges, like mental, physical."

\subsubsection{Discrimination and Xenophobia from Landlords}

All participants maintained that working with landlords can be very difficult. Landlords are sometimes blatantly racist and discriminate against their clients. They also have coy ways of inadvertently making sure participant's clients cannot rent their units. Participants described landlords as often being aggressive and intimidating. Participant \#3 expressed that they are very discriminatory when choosing tenants in order to find their ideal candidate. Participant \#2 said that many landlords or people who are filling a room in their home do not want newcomers occupying their units. He said:

People quite often don't want newcomers there. Not even touching refugees, but just someone who is new to the country, may have a thick accent, there's a lot of racism. So it's either I don't want someone who is not established in Canada, or most likely I don't want that person from that skin colour, that religion, that ethnic group living with me.

Participant \#3 said that many landlords are discriminatory in regards to family size. He said that sometimes landlords make up their own rules in regards to how many people can occupy the unit, whereas the law is actually based on square footage. "They would say a 3 bedroom could only occupy 6 people. A lot of places would say that."

Participant \#4 said that her organization is having a very challenging time in successfully housing unaccompanied refugee minors, as landlords are skeptical of renting to them due to their age. She advocates on their behalf to the landlord and says: "[...] I'll continue to come and visit 
and make sure she's paying her rent and everything, she's maintaining your room and so on." She also said that her workplace faces difficulties housing those with physical and mental disabilities. Furthermore, she noted that "the discrimination is very passive. Sometimes you're not able to touch it, but you feel it." She says that landlords do not directly state "no I'm not renting to, you have no money, or you're black, or you don't speak English." This meaning that landlords are not always direct and their discrimination against her clients cannot always be easily identified as such.

\subsubsection{Stigma Surrounding Ontario Works}

Participants spoke of the stigma that surrounds recipients of welfare from Ontario Works. Participant \#3 stated that huge discrimination exists surrounding welfare, and landlords even write on their online ads that they will not take such recipients:

[J] ust recently I've been going through a lot of ads and they say no $O W$, which is illegal and you're not allowed to say that. But people say it anyways. So huge stigma against people on welfare. Like they're lazy, drug addicts, they don't pay rent, they're going to ruin the apartment, that type of stuff. The second someone finds out they're on welfare their chances go down almost $70 \%$, or like $90 \%$.

Participant \#1 said that sometimes when talking to landlords on the phone and informing them that his clients are welfare recipients, landlords inform him that his clients do not qualify for the unit. Participants \#1, \#2 and \#4 said that they attempt to explain to landlords that because their clients receive welfare, direct deposits can be sent to the landlord by the government instead of relying on the client to pay themselves. They explain that this a complete guarantee that they will receive their monthly payments.

Participant \#4 experiences difficulties once landlords are aware that the client will pay rent through welfare. Once landlords agree to rent to her clients, she is required to have them complete a rental information form. This form is necessary for recipients of Ontario Works to 
submit, as Ontario Works needs the contact information of the landlord in addition to the amount of rent and the address of the accommodation that will be rented. Once she asks them to complete this form; however, she receives hesitation as many landlords do not want to deal with Ontario Works and want clients to pay them directly. Participant \#3 also faces major difficulties with Ontario Works. He said that many landlords require first and last month's rent from his clients in order for them to sign a lease for a unit. Ontario Works is supposed to provide recipients with this amount when they are signing a lease. However, he said this payment of first and last month's rent is not always paid in a timely manner, or Ontario Works will ask for the lease contract before providing the amount. This results in refugee claimants losing out on housing opportunities, as landlords will not let them sign the lease until they receive first and last month's rent.

\subsubsection{Stigma Surrounding Unemployment}

All participants spoke of how unemployment negatively affects the chances of their clients being able to find accommodation. Participants \#1 and \#2 said that some landlords ask their clients for letters of employment, pay stubs, and credit checks in order to be able to rent their unit. Refugee claimants, however, may not be able to provide these as they may not have a history of working in Canada. Participant \#2 said that clients will be denied units because of this, even though they could pay the rent with their welfare. He described how landlords can view his clients:

They find the refugee claimants are very risky tenants. Because they don't have their own income. They ask can I get a letter of employment, they don't have. Can I get a statement of your financial statement? The balance on their account is zero because it's just a chequing account where you put money and you take out just for consumption. Or "I want a credit record." They don't have. So everything plays against them. 
Participants \#1, \#2 and \#4 discussed how it takes too long for refugee claimants to receive work permits. They said that it takes an average of 6 months, which is often after the clients have already left the refugee shelter. Participant \#4 noted “[T]hey don’t mind what kind of job. They want to get out there and work. Rather than getting stuck on welfare that doesn't get you anywhere." Participants \#1 and \#4 said that there is a misconception that if work permits were given in a more timely manner, it would be an incentive for people to come to Canada and claim refugee status in order to work.

\subsubsection{Refugee Claimant's Expectations}

All participants expressed that refugee claimants begin their housing search with unrealistic expectations in regards to what they can afford. Participant \#3 and \#4 noted that many clients want to find accommodations close to the refugee shelter that they are staying at. Unfortunately, this is usually unrealistic as these organizations are in very central locations and therefore in expensive areas of Toronto. Participant \#1 said that clients start off by saying that they want their own place and do not want to consider shared accommodations, even though shared units are less expensive. It takes time and effort for participants to help clients understand that they have to sacrifice certain aspects of what they are looking for in order to align with their current economic situation. He explains:

I say look, you don't get what you want on the first try. You have to have a step by step plan. So for the beginning you have to start somewhere. After one year, and you actually have a record of how you pay your rent, you now know your way around how to be in the community, then you can move on the next best, then the next best, until you get what you want.

Participant \#2 elaborated on how refugee claimant's expectations manifest before arriving in

Canada:

A lot of people come to Canada seeking safety, and they're filled with rumours and stories of how the government will provide for you, they'll give you a home, all of this 
stuff. And they come here and they end up in a homeless shelter where no one cares about them. So there's this high expectation that, even though it's quickly disrupted when they come, it's still there and they still believe they can get something nice with government support.

Participant \#4 discussed how it is difficult for clients to move from the shelter into private market rental spaces, as the shelter has more amenities than what clients are able to afford in the city. Clients experience a downgrade in their living situation.

Participant \#3 highlighted that there can be different housing expectations for those from different cultures, in addition to those that were financially well off in their home country. What may seem like a practical and solid housing choice in Toronto is not necessarily the same opinion in the client's home countries. However, he explains that:

The first month (of house searching) is almost like a coming to terms of what it's like. And I think that's where the expectations kind of change. And then, you almost get a period of stress in between, when you're realizing that what your expectations were might not line up.

This suggests that refugee claimants do eventually come to accept that sacrifices will need to be made if they are to find accommodations.

\subsection{How the Housing Search Affects Participants' Clients}

All participants expressed how the housing search process in Toronto affects their clients in a sad and discouraging way. Participant \#4 stated that the housing search is demoralizing and disappointing for her clients. She said her clients have had landlords who do not answer the door when they arrive or shut doors on their faces, and who hang up the telephone on them in mid conversation. She added that clients also feel pressure to find a place quickly as they will have to leave the shelter once their end date has arrived. Participant \#1 said that his clients can become so upset with their experience that they begin to look outside of the city. Participant \#2 said in regards to how housing searches affects his clients: 
It breaks them. [...] [T] hey had all these dreams and expectations of I'm going to live in Canada, I'm going to live a normal life. I'm going to be able to build my life up back to where it was. And all of a sudden, you're next to homeless. You can barely afford anything. [...] It really demoralizes someone. It beats you down, it exhausts you. It makes you feel like there's no hope. It makes you feel like something is wrong with you. And all of a sudden this country that you thought was a place where you could be safe and more people would welcome you, is just a country where you'll be safe. People are not welcoming you, few Canadians do. Just because of how our society is, it's very individualistic.

While Participant \#3 stated that the housing search is discouraging for his clients, he emphasized that they are "really really resilient people".

\subsection{Work Conditions of Participants}

This section highlights how participants felt about their work and work conditions. This is relevant as work conditions could impact the success of how participants perform their roles in finding housing for their clients. All participants technically work full time regular hours, with the exception of one participant who lives at their organization and therefore works more hours. Yet, all participants work a significant amount of overtime hours. This ranges from 10 hours per week, to over 20 hours per week. Participant \#2's organization allows him to take time off in lieu of these hours. Participant \#1, however, does not log extra hours and considers "it a way of donating to the organization." Participant \#4 logs some hours, but not all. She said in terms of her working hours:

So in this line of field you know when you are coming, you don't know when you are going. Can you imagine? My clients, they are in crisis most of the time. This is traumarelated. I got my bag, I'm walking out, and somebody's coming crying, a young person, oh I have this homework, my teacher didn't do this, oh I'm just coming from this landlord that said I need a letter from you. What do you think I do? Drop my bag.

Participant \#3 said he feels like he is working 24/7, and his organization does not give him time off for overtime hours. He said: "Our burn out, it's really hard. People burn out really hard $[\ldots]$ we're experiencing that a lot. Just because you're on all the time." All participants 
noted that overtime is the nature of this line of work. All said that they feel very supported by their organizations, except for Participant \#3. He answered the question with hesitancy and said that his organization is somewhat supportive. He highlighted that he had a lack of training and a lack of resources at his workplace.

Participants were asked how many other people in their organization help with housing for clients, and if they felt as though this number was adequate. Participant \#2 is the only person at his workplace that fills this role, but noted that his workplace receives 3 summer students for 2 months of the year. Participant \#3 is supported by 6 other people who are capable of helping to search for housing. Participants \#1 and \#4 work with 2 other staff members, yet Participant \#1 also relies heavily on volunteers for extra support. All participants expressed that the number of staff and volunteers is not sufficient enough to manage all the work at the shelters. While Participant \#3 has the highest number of staff that help in finding accommodations for refugee claimants, he feels as though "it's probably never enough people." Participant \#4 expressed frustration at the lack of housing workers at her organization and said that staff are advocating for more.

Answers varied in regards to how working with refugee claimants affected them personally. Participant \#4 shared how her work helps her appreciate what she has:

I think I... The way it affects me, positively, I look at things and I value what I have. [...]And I say wow I want to know more, I want to be able to help this population more, that is what kind of grounded me. Working with this population makes me to reflect, and I kind of appreciate what I have, and it makes me to work even more to help.

She also noted how important self-care is in order to detach herself from her work: "And I do certain things to help me come back to myself when I get home so that I'm able to forget what happened at work." She highlighted that she debriefs and discusses challenges with her work staff before leaving for the day, which helps to not take work home. 
Participant \#3 noted how changes to the Canadian asylum system in 2012, where

timelines were expedited for refugee claimants in terms of submitting documents and having a

hearing at the IRB, have affected both his clients and the people that work with them:

And partially a lot of the stress right now, [...] people would point to the system and how it's changed over the years. And how things go so much faster and people are just so stressed and... it disseminates throughout the community in a really tangible way. If things get really hard, as the system, it impacts your life really directly in how your work manifests. Because there's very little separation from the work you do and the life you live. I wouldn't say it affects you in the same way that it affects refugees, I think it would be wrong to say that, but it fundamentally does affect you in how you do your work and how you live your life.

He also noted how the stress of finding housing can be experienced vicariously through refugee claimants, and provided personal experiences he has gone through with his clients to exemplify how this occurs for him.

Participant \#2 discussed how frustrating it can be to observe his clients get "stuck" in the asylum system:

It's more so... I guess... sad? It doesn't affect me too much, I have a pretty thick skin. But it's frustrating. I always tell everyone the most intelligent, the most beautiful, the most kind people that I have met in my life have been in the refugee home. Just the other day I was helping a guy who is a doctor and his resume was stacked, and I was like you could get any job you want. And here he is on welfare. And so it's frustrating because you meet these amazing people with so much potential, [...] and they're stuck. And you try to help them and you can't help them, you can only do so much. So the job is frustrating because of that, it's sad because of that. You have families come in, and there's nowhere you can send them. You might keep them in your boardroom, you might keep them in the basement, but when the next one comes what do you do? You send them to Tim Horton's or something.

He went on to discuss how his experience at his workplace has made him disappointed in

how Canadians welcome refugee claimants:

And the last thing that's frustrating is how [...] selfish and self-centered a lot of Canadian people are, like in our context specifically. [...]My dream is to reach out to churches so that churches could offer their home. Like Congregants could offer their homes, basement rooms, to refugees. You could even charge rent, you can even benefit financially from this. But if you follow a religion that says you should love other people 
and you should welcome people in, you should love your neighbour... there's people coming in and they're not being loved and have no help. So it would be really awesome not even just from a Christian context but Canadians, Muslims, Christians, everybody could just... if you have the capacity, take someone in. Most refugees are not dangerous, most refugees are really kind people. You could screen them, you could do all types of stuff. [...] [F] rom a Christian context, if even 10 people from each church in Toronto offered some type of temporary accommodation, the problem would be alleviated so much. And then if mosques did the same thing, synagogues, if people of faith and people who don't have a faith, just nice, moral people, offered to help, the situation would be alleviated. But unfortunately, just human nature and the way we are in the West, if helping someone means inconvenience for us or it discomforts us, we usually don't want to do it. We are really focused on ourselves and our own issues, which are real issues, but we also have the solution. The government is not the solution, they're only going to do so much. So that's another frustration. Trying to move and motivate people.

Participant \#1 highlighted how his clients share with him the traumas they experienced in their home country: "[A]s a human being you listen to their story, and it stays with you a little bit. It hurts you. So I have what they call vicarious trauma." He shared that when it comes time for a client to move out of the shelter, he never says goodbye as it is very difficult to lose someone whom he has formed such a strong bond with. He explained:

It's very traumatizing because for us as human beings we want permanent relationships. We want people to be part of us forever. But if you keep losing them, you think what is the meaning, what am I doing? It's really like grabbing somebody and you never grabbed them. [...] And you think, should I be more attached or should I be less attached? So that when they leave it doesn't hurt. But you have to be attached because you want to serve in a personal way.

While all participants are affected by their job, each one experienced a different range of emotions stemming from their day-to-day interactions with their clients and the limitations that their role as an FLW can have on the well-being of their clients.

\subsection{Participants' Policy Recommendations}

Participants were asked what kind of changes they would like to see happen in the housing market, from a policy and regulations perspective, which would make it easier to do their job. 
Participant \#4 stressed that rent control is key to improving the housing issue. She said that the government must build more housing and control rent prices. Participant \#3 also said that building low income housing, in addition to maintaining current buildings, is needed. Participant \#1 believes that more houses must be built that are catered to those who are the most in need. He explains:

You identify what kind of immigrants come to Canada, where is the demand. What kind of people are looking for housing. Who are the most hurt. So you begin supply tailored to their demand. Like people who are first time owners, or people looking for rental properties. So if there is going to be supply, the government needs to put in some money to encourage the private sector to invest in this area in a way that focuses on the low income bracket. But if that is not done and they leave it to the market to define who wants to build and build what you want and where you want, then it's not going to address the needs of those who are really really in need of housing.

Participant \#1 also said that in order to address the housing problem for refugee claimants, more staff is necessary. He explained that a program which is pre-emptive should be developed, where housing for clients is arranged before the client is even moving out. This would involve building relationships with buildings and landlords, who can then contact the shelter to notify the organization that there will be an availability. It would also involve past clients notifying the shelter when they are moving out, so that new clients can move in.

So for that to happen, you really need to have somebody out there to go and explore and kind of profile different landlords, owners. How do you deal with owners, [...] how do you deal with property managers. [...] So we need somebody to do that kind of work in a very very very organized way."

He explained that by having someone fill this role, relationships can be built between the shelter and the community, the housing process will move faster, and clients will be able to move out more rapidly.

Furthermore, Participant \#1 disclosed that policy changes should be implemented that results in refugee claimants choosing other cities than Toronto to settle in, in order to alleviate 
the high numbers of refugee claimants in the city. He stated that Toronto receives way more refugee claimants than any other city in Canada, and incentives could be put in place which have the effect of moving people elsewhere. The government could make other cities attractive to refugee claimants in order to decongest Toronto. He also maintains that work permits should be given to refugee claimants in a more timely manner. He said that it currently takes approximately 6 months to receive a work permit, and that this delay perpetuates the use of welfare as refugee claimants cannot work.

Participant \#2 revealed that he wishes the government could regulate and review rental ads on websites such as Kijiji and Craigslist in order to prevent the abuse and discrimination that currently goes on. He explained:

You can't deny someone based off their race or ethnicity, but it happens. You can't deny someone, a newcomer based off of not having credit, but it happens. The ads clearly discriminate all the time. A good $40 \%$ of them or so, 30 to $40 \%$. So technically we could do something about it, but the amount of time and resources and effort you would have to put into that, and that the client would have to put into that, is just enormous. [...] I would love to see the government being more active in preventing abuses before a complaint is filed. Having a team, going through ads, and calling people and warning them, and giving them warning letters.

Participant \#1 expressed similar ideas about the need for accountability of landlord's behaviours:

There are things that landlords have been allowed to do that are counterproductive. Discrimination which is not supervised. [...]I know there are provisions people can take, applicants can take the landlords to court and so on and so forth. But really nobody who is this poor is going to spend time going to court. First of all they don't even know how to do court things. So I think there should be more supervision on the side of, maybe there should be, apart from the Tenants and Landlords Act, which is the law, but maybe there should be an inspectorate or I think there should be a place where complaints are addressed in a very speedy way at a very low cost.

Participant \#2 said that more shelter space is necessary in Toronto, as homeless shelters,

youth shelters and refugee shelters are all over capacity. He said:

So you have newcomers, refugees coming, who end up homeless because all of the refugee homes are full and because our clients cannot move out to find anywhere. They 
either end up sleeping on the street or sleeping in stranger's homes, or they go to a homeless shelter and they're completely terrified.

He emphasized that because his clients are unable to move out fast enough due to the barriers they face in housing, refugee claimants in the city are unable to stay at his workplace because there is no space for them. This results in homelessness or attempting to find space at other over capacity shelters. He said: "[T]hese are people who fled war, had to get fake passports, had to get smuggled into Canada and they think they're safe. And now they're sleeping in a park with people approaching them. It's, it's not justice. It's human rights violations.” He said more refugee homes should be opened in the city in order to house more refugee claimants and to relieve other organizations.

\section{CHAPTER 6: ANALYSIS}

This chapter will present an analysis of the answers and discussions provided by participants during their interviews. The experiences expressed by the participants complement the previous literature on the topic, and also provide an insightful insider's perspective of working with refugee claimants in Toronto. Firstly, the role of FLWs will be analyzed using the AOP approach. Next, the barriers participants face in their work will be evaluated. Finally, participant's attitudes and their reflections on their role will be discussed.

\subsection{The Role of Frontline Workers}

It is clear from the interviews with the participants that the role of an FLW in a refugee shelter goes far beyond simply providing a service pertaining to the basic settlement process and helping provide advice through the claim process. The participants demonstrated that they are responsive to the potential trauma some of their clients may have experienced and are mindful of the lack of knowledge that both unaccompanied minors and adult refugee claimants may have. 
Participants described taking on a very person-centered, humanitarian role by helping their clients with all aspects of settlement - from their basic needs, learning basic skills, applying to work and school, finding accommodation, accessing counselling, and acquiring medication if needed. In this sense, the participants provide appropriate and sensitive services in order to educate refugee claimants on how the asylum and housing systems work and to empower them to advocate on their own behalf.

This can be seen through the answers provided pertaining to refugees' expectations of the kinds of housing they will be able to access in Toronto. Participants all expressed that they experienced difficulties finding housing for their clients, as their client's expectations were unrealistic with regards to what they could afford. While participants could have informed their clients at that moment that it would be highly unlikely to find something that met their requirements, they often let their clients come to those realizations on their own. This approach complements AOP. While the participants have decision-making power, ultimately their clients have the final say. Interestingly, practicing AOP in these situations could be viewed as a barrier at times, as having to respect unrealistic expectations of claimants can result in accessing affordable accommodation in a less timeless manner. Ultimately, however, the participants favoured the AOP approach and accepted the challenge of trying to accommodate their clients' needs and ensured that their clients retained a significant share of the decision-making process. While this may not always result in finding accommodation in the fastest way or at the lowest cost, it prioritizes helping the claimants find a place to call home.

All participants use a variety of methods in order to find accommodation in Toronto. This can range from standard practices such as visiting online websites that list available units, but also vary to more obscure ways such as going into shops and community centres to look for 
advertisements for rental units. Participants work in conjunction with refugee claimants to determine what kind of housing they are seeking and can access. This can be seen in how participants organized sessions that taught their clients how to navigate housing in Toronto, or when participants had one-on-one sessions to educate their clients on this system. Moreover, they encourage refugee claimants to guide the decision-making process by putting their client's needs and desires first. They prepare them on how to interact with landlords and allow clients to decide the extent to which they want their FLW to be involved in communications with prospective landlords. Participants encourage their clients to use their own resources wherever possible to expand their search. This collaborative approach provides refugee claimants with the tools to advocate on behalf of themselves and allows them to have the final say in where they will live.

Participants expressed how beneficial it is to be present during house viewings and to call on behalf of their clients. It is clear that by having an FLW who is proficient in English and who also has a firm grasp of rental policies and the housing market, the likelihood of housing refugee claimants increases. Through their work experience, the participants have acquired a strong understanding of the kinds of discrimination that can materialize in these interactions with landlords, and they are prepared to attempt to combat this. Furthermore, the stigma surrounding Ontario Works is an additional barrier to securing accommodation. Through responses in the interviews, it is apparent that participants are able to reduce these varying types of discrimination committed by landlords in some instances by acting as an intermediary between landlords and their clients. This can be seen when they described the tactics they use to persuade landlords that their clients will be an ideal tenant. They described how the Government of Ontario can directly send the tenant's rent to landlord's bank accounts, and Participant \#4 said that she tells landlords 
that she will continue to monitor her clients and can be a point of contact. In this sense, the participants provide a service, which is sensitive and specific to their clients, and apply an appropriate degree of direct help when interacting with landlords whether it is to overcome a language barrier, systemic barrier, or challenge the stigma associated with social assistance.

The socio-political status of refugee claimants was a notable deterrent to landlords, and this posed as a barrier when the participants searched for housing. In order to circumvent this issue, three of the participants, understanding the significance of language, used words such as "newcomer" or "friend" instead of refugee claimant when speaking with landlords. Furthermore, Participant \#2 said that he uses the term "government support" instead of "welfare" when speaking with landlords, believing that this technique may make the landlord believe the client is a sponsored refugee instead of a claimant. All participants demonstrated that they keep the details that they share about their clients to a minimum. These findings suggest that participants are aware of the precarious and vulnerable status of refugee claimants and that this tends to render them undesirable compared to other sections of society that, by political and socioeconomic status, occupy a higher place in the social hierarchy. Furthermore, they attempt to bypass this by altering the language they use and limiting the details that they share to protect their clients from discrimination and negative assumptions. This exhibits an adherence to the AOP approach as they are sensitive to the vulnerable status of their clients and tailor the delivery of their service appropriately to reduce discrimination.

\subsection{Barriers}

This section analyzes 3 categories of barriers that participants face in their work; the lack of subsidized and affordable housing in Toronto, discrimination refugee claimants face, and participants' work conditions. 


\subsubsection{Lack of Subsidized and Affordable Housing}

The lack of affordable housing in Toronto reflects an intersection of structural inequalities. As funding and support for affordable housing from the federal and provincial government has decreased since 1993 and 1995, respectively, this responsibility has shifted to the municipal government and private sector. Since the early 2000s, however, the Federal Government and the Government of Ontario have supported and funded several initiatives to handle the growing need for affordable and social housing, yet not to the same extent as in past decades prior to the mid-90s (Association of Municipalities of Ontario [AMO], 2017). Reliance on the municipal government and the private sector in Toronto to implement large scale projects to construct affordable and subsidized housing has been less than successful. As Toronto continues to expand in population and size, the focus from the private sector has been a proliferation of condo developments with drastically fewer investments in building apartments for rent. While this is beneficial for professionals and investors, who already occupy a more privileged step on the social ladder, refugee claimants, whose socio-economic position is much lower, are negatively impacted. The private sector has acknowledged that there is a significant demand and apparent need for such housing, one example being the Private Sector Housing Round Table, chaired by Councillor Ana Bailao in 2012. A report culminating from this round table discussion outlined several recommendations such as creating tax incentives for companies, modifying zoning regulations, investing in affordable ownership, increasing income support and reinvesting in private rental communities (Private Sector Housing Round Table Report, 2012). While these actions would certainly yield positive results and incent the private sector to invest in more affordable rental units, little progress has actually been made. 
Such structural inequalities are present in the realm of subsidized housing as well. Participants' clients are rarely able to secure subsidized housing in the city as the wait list is approximately 10 years and existing subsidized housing is in need of repair, leading to relocation for those dwelling in units that are in disrepair and longer wait times. Refugee claimants are therefore essentially forced to look for housing in the private sector. However, the monthly amount paid to refugee claimants from Ontario Works is insufficient to keep up with private sector costs. As a result, it takes a significant amount of time and effort to find affordable, available and accessible units for this population. Participants said that this significant amount of time keeps shelters full for longer periods, and therefore they must turn away other refugee claimants. To make matters worse, landlords in the private sector are able to manage the housing market by deciding monthly rental prices for their units, with limited intervention from the public sector. This thus limits opportunities for refugee claimants to find affordable housing. The capitalist-driven housing model exemplified in the Toronto housing market severely impacts vulnerable populations. The mass production of expensive rental condos currently taking place displaces people, as they are unaffordable and unrealistic for most. Even shelters are not immune to this displacement. For instance, Cornerstone Place and Beatrice House were shut down, in 2014 and 2015 respectively, in order to make room for condo developments (Balkissoon, 2015). Additionally, Hope Shelter closed down in 2015 as it was bought by the University of Toronto (Balkissoon, 2015). The City of Toronto currently has a total capacity of 5,258 beds in its shelters (City of Toronto, 2017). While this appears to be a sizeable amount and valiant effort to reduce homelessness, as of July 26th 2017, men's shelters are 95\% full, women's shelters are 97\% full, youth shelters are 97\% full, and family shelters are 100\% full (City of Toronto, 2017). Participants spoke of how their shelters are constantly at capacity, and when 
spots are available they are filled right away. This leads one to wonder how many refugee claimants are left homeless in Toronto as the different types of shelters available to them are at capacity. Moreover, this depicts another element of inequality whereby social programs aimed at eliminating homelessness are constrained despite the relative wealth of a developed nation, such as Canada.

The prioritization of building condos and expensive housing and buildings illustrates that there is a hierarchy representing whose needs are more important, with the needs of refugee claimants and other vulnerable populations clearly being very low.

\subsubsection{Discrimination}

Participants described a range of ways in which refugee claimants experience discrimination in the housing market. Intentional discrimination by landlords occurs through racism, intolerance, stigma against refugees and a general unwillingness to rent to newcomers. These micro social relations between landlords and refugee claimants are unmonitored, and hence there are fewer repercussions for their actions. For example, Participant \#3 spoke of ads online that directly state that the landlord will not rent to recipients of Ontario Works. This stigma and misconception of those who receive welfare negatively affects refugee claimants, who therefore not only have to worry about preparing for their hearing but also must dedicate a significant amount of time to finding a landlord that will rent to them.

Moreover, systemic discrimination is rife in the private housing market. Participants described how landlords ask for credit checks, financial statements, and letters of employment from potential renters. These documents cannot be provided by refugee claimants. Due to policy surrounding when work permits can be issued, many refugee claimants are still unemployed when they are looking for accommodation. Their bank accounts, therefore, only have enough for 
survival and they have not had enough time to build up a credit score. These macro social relations, which form between refugee claimants and the structure of the asylum system and the housing market, create inequalities for those who do not fit a particular model of an ideal tenant. Landlords are seeking very specific tenants; those that are Canadian citizens who have employment, a credit record, and a sufficient amount of money in their bank account. These structural inequalities, consequently, limit the capacity of refugee claimants to find accommodation and reinforce the notion that refugee claimants are poor, unemployed, and live off social assistance, because they are not provided with opportunities to change these factors. Danso (2009) describes how Canadians do not take these structural barriers into consideration when making judgements about vulnerable populations:

Many mainstream Canadians accuse visible minorities of not integrating into Canadian society. Paradoxically, however, they fail to acknowledge the impediments that are placed in the path of these same immigrants as they attempt to integrate in their new country (p. 544).

In other words, Canadians can be unaware of the many barriers that refugees must face to get to Canada, to start their lives over again, and to re-establish stability in a new country. However, Canadians may notice the effects of these barriers, such as unemployment and poverty. They may attribute these effects to refugees' individual decisions and not to systemic barriers over which refugees have no control. In fact, such systemic barriers can be levelled by granting work permits. Crepeau and Barutciski (1994) explain the positive outcomes of providing refugees with the opportunity to work:

"The social status obtained by gainful employment is particularly important for refugees who have been traumatized by a forced exile and who are attempting to maintain a minimum of dignity while they are given refuge. Furthermore, participating in the workforce allows refugees to contribute economically to a society and thereby acknowledge the generosity of the host state in providing refuge." (p. 4) 
Granting work permits would not only alter how refugee claimants are construed by landlords and the wider population, but would also alleviate the additional burden on shelters and the welfare system.

\subsubsection{Work Conditions of Participants}

Most participants spoke highly of their place of work, in addition to their staff and supervisors, and felt supported by their organization. However, negative implications inherent to this kind of work arose in the interviews. Participants \#1 and \#2 discussed how refugee shelters are often supported through donations, and therefore lack resources and enough funding to support organizational projects and programs. There is limited financial support from the public sector for these services. This limited support is highly questionable, as it seems as though Canada's asylum system would not function properly without the help of FLWs. All participants reported working a considerable amount of overtime hours, and all agreed that refugee shelters are understaffed. Only one participant was able to take time off in lieu, and it seems as though none are paid for their overtime hours. It is possible that supervisors, managers and directors of refugee shelters are not adequately monitoring the hours of their staff, or they are not considering the repercussions of letting their workers burn out. Their lack of monitoring employee work hours and their reluctance to offer time off in lieu may lead to their employees experiencing burnout. This burnout will in turn affect how FLWs perform their duties and the overall success of the organization. Participant \#3 did address burnout in his interview and said that rates are high at his organization. It is possible that this could lead to FLWs either leaving their place of work or needing to take time off from work for mental health reasons. Clearly, without sufficient resources and support from both the government and upper management at the shelters, it is 
difficult for FLWs to adequately challenge the structural inequalities affecting their clients to their full potential.

\subsection{Participant's Attitudes and Reflections}

Participants demonstrated through their responses that they take on a person-centred approach in their positions. They are able to take on a critical and reflective stance on their position within the social structure of their employment.

Participants displayed a genuine understanding of how oppressions that refugee claimants may face interconnect with one another, and have influence over how they are treated and the situations that they may face. They understand that there are larger factors at play that their clients cannot control, and it is not necessarily their client's individual choices that determine their ultimate fate. This is reflected in interviews when participants discussed how policies such as timelines for work permits hinder their client's ability to settle, and when they described the overall stigma and xenophobia of refugees and newcomers. Furthermore, Participant \#4 directly discussed the difficulties unaccompanied refugee minors face due to their age, in addition to clients with physical disabilities.

Moreover, they are aware of their privilege and social position in comparison to their clients. This was exhibited in Participant \#4's response when she discussed how her work makes her acknowledge and be appreciative of what she has, such as a home and family. Participant \#3 demonstrated awareness of his privilege when he stated that it would be inappropriate to say that the housing experience affects him the same way it does his clients.

It is clear, however, that working with this vulnerable population can impact an FLWs well-being. All participants spoke of the difficulties they face on behalf of their clients, and how the housing search affects their clients in discouraging ways. It is possible that participants 
experience vicarious trauma not only through their clients' experiences but also in trying to help them settle in the city. Three participants spoke of the implications of working with this population has on themselves, such as when Participant \#2 discussed how he has to turn refugee claimants away as the shelter is at capacity. He expressed his concern regarding where these people will sleep, and said he believes Canadians are not doing enough to welcome refugees. Additionally, Participant \#1 discussed how he experiences vicarious trauma through listening to the stories of his clients and how he faces difficulty saying goodbye when it comes time for his clients to move out of the shelter.

\section{CHAPTER 7: POLICY RECOMMENDATIONS}

The implementation of the following policy recommendations would greatly benefit the overall success of Canada's settlement of refugee claimants and remove some of the barriers FLWs face facilitating their resettlement. These recommendations are influenced by the responses which participants provided in their interviews.

\section{More affordable and social housing that is catered to those who are in significant need}

must be built in Toronto. This is necessary in order to alleviate the city's shelters and to address its homeless population. A wait-list of 10 years for social housing is inadequate and must be addressed. It is critical to reallocate the responsibility of affordable and social housing to the federal and provincial government. The demand is too large and too urgent to rely on marketdriven solutions and modest government intervention. The most effective solution to dealing with the housing crisis - which would in turn benefit refugee claimants - would be for the federal and provincial government to fund and support large scale projects for subsidized and affordable 
housing as both did in the 1950s through to the 1980s (AMO, 2017). Such actions would reduce the structural inequalities which exist when it comes to accessing housing in Toronto.

\section{Canadian citizens and those living in Canada should be motivated and encouraged to} rent out an extra room in their home to refugees and refugee claimants if they have the space to do so. One non-profit organization, Roofs for Refugees, operates in Toronto and Ottawa and facilitates community members renting their space to refugees. However, it is entirely dependent on donations and is run by volunteers (Roofs For Refugees, n.d.). As well, no statistics are provided about the program's usage, and interestingly, none of the participants of this study mentioned using this service for their clients. Hence, greater funding and support from the public sector, as well as more exposure by the media would be critical to truly using this housing solution to its fullest potential.

\section{The Federal Government of Canada should partner with refugee shelters by providing} them with funding. It is evident that the asylum process in Canada is successful in its own right due to the hard work of FLWs. They make sure that clients understand this complex system, that they fill out their forms and applications correctly, and that they are prepared and attend their refugee hearings. They help refugees overcome and challenge barriers in society in order to provide them with safe refuge. The government should therefore acknowledge their hard work through funding. This funding would allow more staff to be hired, which would alleviate burnout. It would also allow more shelters to have staff that can accompany their clients to view available housing.

4. The government should open their own refugee specific shelters. Not only would this option help to alleviate the shelter systems, the government would be able to easily monitor refugee claimants. 


\section{Work permits should be issued for refugee claimants as soon as they declare that they}

will be making a claim in Canada. Refugee claimants would therefore be able to begin acquiring funds in a more timely manner and would no longer have to resort to relying on Ontario Works. This implementation would in turn alleviate shelters, as refugee claimants would have more savings and would therefore have access to more housing options. If they are successful in finding employment, they would be able to provide letters of employment and financial statements to landlords when requested.

\section{A governing body that monitors housing discrimination should be implemented to hold landlords accountable for their tenant decision making. This body, funded and run by the} provincial government, would audit landlords by monitoring their advertisements of their accommodation on online websites, in addition to random checks of tenant viewings and applications. This body could issue fines, or temporarily halt landlords from being able to rent their units in order to deter discrimination. This would help to ensure that landlords and housing provider's rental policies and practices abide by the Human Rights Code (CERA, 2009).

\section{A mandatory course for landlords and housing providers should be put into action, to} educate these individuals on all aspects of housing discrimination, including how it will be monitored and what the consequences will be if discrimination is discovered. This could be implemented through a partnership between provincial or federal governments in addition to FLWs from refugee shelters. This course would also be an opportunity to educate landlords about refugee claimants, and other marginalized groups, and the hardships they experience in searching for housing. It would be explained during courses that refugee claimants are not risky tenants, as direct deposits can be made to landlord's bank accounts from Ontario Works each month if deciding to rent to this population. 


\section{An IRB office, where refugee hearings are held, should be instituted in a city that is}

relatively close to Toronto. Toronto is currently the only city in Ontario that has an IRB office where hearings are held, which presumably contributes to the high number of refugee claimants who come to the city. A new IRB office would alleviate the amount of refugee claimants that feel as though they must go to Toronto in order to have their hearing and then subsequently settle in that general area.

\section{An easily accessible system for people to report the discrimination that they believe was} inflicted on them should be created. Participants discussed how the current system, whereby refugee claimants can file an application with the Human Rights Tribunal of Ontario, is timely, costly, and inaccessible. Refugees do not have the time or means to complete this as they are focused on their claim, establishing themselves, and finding a home. A telephone number could be created to report this discrimination, and complaints could be stored and monitored in profiles of landlords. This tool could help decide which landlords should be audited to see if they are complying with The Human Rights Code.

\section{CHAPTER 8: CONCLUSION}

FLWs who work at refugee shelters play a vital role in the overall success of refugee claimants in Canada. While refugee claimants face numerous complex barriers in accessing housing, their chances of being housed are increased when an FLW acts as an intermediary between client and landlord. FLWs educate refugee claimants, provide them with the tools necessary to navigate the complexities of the asylum and housing systems in Canada, and when necessary, advocate on their behalf when communicating with landlords. Participants' naturally adopt the AOP approach when working with their clients and challenge oppressions and 
inequalities that they encounter. Through a collaborative approach, they not only advocate on behalf of their clients but also teach them to advocate for themselves. They provide refugee claimants with support in order to facilitate their successful settlement in their new community.

While their role is invaluable, concerns exist in their place of work. They are overworked, as demonstrated through their many hours of overtime. And the settlement organizations they work for are also considerably understaffed. More FLWs and housing support workers are necessary in order to prevent burnout of employees, which in turn would reinvigorate employees to do more for their clients. Emphasis from both government and upper management should be placed on FLWs mental well-being, as it is clear that they are affected by their experiences at work and are susceptible to vicarious trauma.

Finding a place to call home is a crucial step in the proper integration of refugee claimants, and further research on how to rectify discrimination taking place in the housing market is necessary. In this research project, it has been revealed that landlords are not following their obligations under the Human Rights Code with regards to how they choose tenants for their accommodation. Landlords and housing providers should be monitored more strictly in their decision-making, and additional policies should be put in place to hold them accountable for their actions. Providing sponsored refugees with housing when they arrive to Canada and not treating refugee claimants equally creates a two-tiered system and may perpetuate stigma of the latter category. Furthermore, the lack of affordable and social housing in Toronto has proven to be a barrier for refugee claimants and the FLWs helping them, yet this study is just a glimpse into a much larger housing crisis that affects many marginalized groups. And while this paper has discussed discrimination that takes place before finding accommodation, further research is needed on the treatment of this population by landlords after they have moved in. Significant 
changes are needed in Toronto's and Canada's housing system in order to live up to its international reputation as an open and welcoming country for newcomers. 


\section{Appendices}

\section{RYERSON}

UNIVERSITY

\section{RESEARCH PARTICIPANTS WANTED}

Finding A Place to Call Home: The Experience of Front Line Workers Searching for Housing for Refugee Claimants in Toronto

Do you work at a refugee-specific shelter and help clients find housing in the Toronto area? Do you have a minimum of 1.5 years' experience?

You may be eligible to participate in a study regarding the barriers that frontline workers face when searching for housing for refugee claimants.

\section{Purpose of the study:}

This study is designed to explore the experiences of frontline workers when they are searching for housing for refugee claimants in Toronto. This study intends to analyse recurring themes and challenges that are expressed by participants, and aims to highlight the importance of frontline workers and refugee shelters. Approximately 5 participants will be recruited for this study from 5 different refugee shelters. Participants are eligible if they work in a refugee shelter, whose tasks involve searching for housing for refugee claimants, and have 1.5 years' experience working in this field. The results of this study will be used in the investigators Major Research Paper in partial completion of a Master's of Immigration and Settlement Studies at Ryerson University.

What does this study involve?

- You will be asked to complete an interview with the investigator, River A. Shaw, which will be approximately 1 hour in length.

\section{Participants will be reimbursed for transportation costs if necessary. All queries are confidential.}

If interested, please contact:

River A. Shaw

river.shaw@ryerson.ca

*Please send inquiries from a personal email instead of a work email.

This study has been reviewed and approved by the Ryerson Research Ethics Board. 


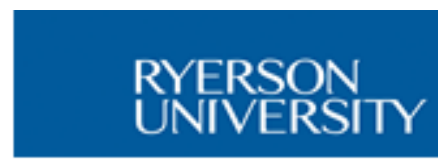

Ryerson University

Consent Agreement

You are being invited to participate in a research study. Please read this consent form so that you understand what your participation will involve. Before you consent to participate, please ask any questions to be sure you understand what your participation will involve.

\section{FINDING A PLACE TO CALL HOME: THE EXPERIENCES THAT FRONTLINE WORKERS FACE WHEN SEARCHING FOR HOUSING FOR REFUGEE CLAIMANTS IN TORONTO}

INVESTIGATORS: This research study is being conducted by River A. Shaw, a graduate student in Immigration and Settlement Studies, working under the supervision of Dr. Idil Atak. If you have any questions or concerns about the research, please feel free to contact River A. Shaw at river.shaw@ryerson.ca or Dr. Idil Atak at idil.atak@ryerson.ca.

PURPOSE OF THE STUDY: This study is designed to explore the experiences of frontline workers when they are searching for housing for refugee claimants in Toronto. This study intends to analyse recurring themes and challenges that are expressed by participants, and aims to highlight the importance of frontline workers and refugee shelters. Approximately 5 participants will be recruited for this study from 5 different refugee shelters. Participants are eligible if they work in a refugee shelter, whose tasks involve searching for housing for refugee claimants, and have 1.5 years' experience working in this field. The results of this study will be used in the investigators Major Research Paper in partial completion of a Master's of Immigration and Settlement Studies at Ryerson University.

Participants will ideally be a mix of both men and women, who have been employed as frontline workers at refuge shelters in Toronto, and whose tasks include searching for housing for refugee claimants. Participants must have a minimum of 1.5 years' experience in this field.

WHAT PARTICIPATION MEANS: If you volunteer to participate in this study, you will be asked to complete an in-person interview with the investigator, River A Shaw. The interview will last approximately 1 hour.

Examples of questions that will be asked include:

Could you please describe the process of how you go about finding housing for refugee claimants?

Are there any specific neighbourhoods of Toronto where you are somewhat sure that your clients will find housing? If so, which neighbourhoods are these? 
Interviews will take place where you feel most comfortable. This can include a study room at the Student Learning Centre at Ryerson University, or at a coffee shop. Demographic data including name, gender, telephone number and email will be collected. If interested in research findings, you may request to be sent the final version of the Major Research Paper at the end of this Consent form.

POTENTIAL BENEFITS: The experiences of frontline workers are underrepresented in literature, and your participation in this research project will therefore contribute to filling in this gap. By participating, you may benefit from looking back on your experiences thus far in your career and working with this vulnerable population. I cannot guarantee, however, that you will receive any benefits from participating in this study.

WHAT ARE THE POTENTIAL RISKS TO YOU AS A PARTICIPANT: Potential risks for participating in this study are very low. There is potential for emotional risk or discomfort in this research as personal questions will be asked. If at any time you begin to feel uncomfortable, you may skip answering a question, or stop participation temporarily or permanently. Breaks are accepted and encouraged during interviews. If needed, a list of free counselling services and crisis phone numbers will be provided.

Additionally, your identity may become known to your employer and could impact your employment, particularly if you say something negative about your agency, etc. To mitigate this, I will allow participants to review any direct quotes or information that will be included in the MRP. You may revise statements to ensure your identity remains confidential. Myself, as well as my supervisor Dr. Idil Atak, will ensure that information that can potentially identify you, such as the agency where you work or a very specific circumstance, will be de-identified in the MRP.

Although there are no planned disseminations of this MRP, I will be sending the MRP to participants if they wish. This means that other participants may read the paper as well, and may potentially share it. This means there is potential risk of your identity being revealed. As stated above, myself, as well as my supervisor Dr. Idil Atak, will ensure that information that can potentially identify you will be de-identified in the MRP.

\section{CONFIDENTIALITY:}

As interviews will be audio-recorded, you will have the right to review and edit transcript recordings and transcripts to make sure you are being quoted correctly. All recordings and transcripts will be stored on the investigators laptop, which will be encoded and encrypted. All recordings and transcripts of interviews will only be accessible by the investigator, River A. Shaw as well as my supervisor Dr. Idil Atak. To ensure confidentiality, pseudonyms will be assigned for all participants and places of work will not be stated.

All collected and recorded data will be kept for 1 year, and then destroyed. Information will not be released to any third party.

\section{REIMBURSEMENT FOR PARTICIPATION:}

Participants will not be paid to participate in this study. The cost of public transportation can be reimbursed to you if needed. This will be paid to you in TTC tokens. 
VOLUNTARY PARTICIPATION AND WITHDRAWAL: Your participation in this study is completely voluntary. You can choose whether to be in this study or not. If any question makes you uncomfortable, you can skip that question. You may stop participating at any time and you will still be given the incentives and reimbursements described above. If you choose to stop participating, you may also choose to not have your data included in the study. Your choice of whether or not to participate will not influence your future relations with Ryerson University or the investigator River A. Shaw involved in the research.

QUESTIONS ABOUT THE STUDY: If you have any questions about the research now, please ask. If you have questions later about the research, you may contact:

River Shaw

river.shaw@ryerson.ca

Dr. Idil Atak

416-979-5000 Ext. 3255

idil.atak@ryerson.ca

This study has been reviewed by the Ryerson University Research Ethics Board. If you have questions regarding your rights as a participant in this study please contact:

Research Ethics Board

c/o Office of the Vice President, Research and Innovation

Ryerson University

350 Victoria Street

Toronto, ON M5B 2K3

416-979-5042

rebchair@ryerson.ca 
FINDING A PLACE TO CALL HOME: THE EXPERIENCES THAT FRONTLINE

WORKERS FACE WHEN SEARCHING FOR HOUSING FOR REFUGEE

CLAIMANTS IN TORONTO

\section{CONFIRMATION OF AGREEMENT:}

Your signature below indicates that you have read the information in this agreement and have had a chance to ask any questions you have about the study. Your signature also indicates that you agree to participate in the study and have been told that you can change your mind and withdraw your consent to participate at any time. You have been given a copy of this agreement. You have been told that by signing this consent agreement you are not giving up any of your legal rights.

Name of Participant (please print)

Signature of Participant

Date

I agree to be audio-recorded for the purposes of this study. I understand how these recordings will be stored and destroyed.

Signature of Participant

Date

I understand that due to the nature of the Internet, there is no guarantee of confidentiality or security of information that I provide if I participate via video chat.

Signature of Participant

Date

I am interested in the findings of this research study and wish to be contacted upon completion.

Signature of Participant

Date 


\section{Interview Questions}

1. Can you tell me about the work that is done at this organization?

2. How long have you been working at this organization?

3. How long have you been in your current position?

4. Can you describe your role at this organization? What are your day-to-day tasks?

5. How long you have been helping in the settlement of refugees/refugee claimants in Toronto?

6. Can you describe the process of how you go about finding housing for refugee claimants?

7. Do you always call landlords with regards to available units on behalf of your clients?

8. Do your clients choose how much help they would like to receive?

9. Do any of your clients choose to find housing on their own?

10. Do some choose to accept help from your organization while doing their own independent research as well?

11. When calling landlords or apartment complexes, do you inform them that you are calling on behalf of a refugee/refugee centre? When/If you do inform them of this, what type of reactions do you receive? (surprised, angry, apprehensive, happy, curious)

12. Does someone from your organization accompany the client to view the unit, or does the client go alone? Can you please explain why this takes place?

13. Do you know of specific landlords or organizations that you reach out to when housing is needed?

14. Are there any specific neighbourhoods of Toronto where you are somewhat sure that your clients will find housing? If so, which neighbourhoods are these?

15. What are some of the challenges that you face when attempting to find housing for refugee claimants?

16. On average, how long does it take to find housing for a client?

17. What are some general criteria for housing (in terms of size/type of housing/housing layout) sought by refugee claimants?

18. Considering the state of Toronto's housing market, do the refugee claimants you help have realistic criteria/requirements for their prospective housing (in terms of their preferred location, apartment size, building amenities, etc.)?

19. How do you think the overall housing search experience affects your clients?

\section{Background Information and Work Conditions}

20. How many people in your organization have the same role as you?

- How do you feel about this number?

21. How many hours do you work in a week?

22. Do you ever work overtime? If so, how often?

23. Do you feel as though you work in a supportive work environment? 
24. Does your work provide you with adequate resources to accomplish your role in finding accommodation?

25. What kind of changes would you like to see happen in the housing market, from a policy and regulations perspective, which would make it easier to do your job?

26. Does working with this vulnerable population affect you personally? How so?

27. How does the overall housing search experience affect you?

28. Are there any general challenges you encounter that were not discussed in this interview that you would like to bring up? 


\section{References}

Agic, B., McKenzie, K., Tuck, A. \& Antwi, M. (2016, January). Supporting the mental health of refugees to Canada. Retrieved from http://www.mentalhealthcommission.ca/sites/default /files/2016-01-25_refugee_mental_health_backgrounder_0.pdf

Association of Municipalities Ontario (2017, January). Housing in Ontario: A primer for AMO members. Retrieved from https://www.amo.on.ca/AMO-PDFs/Reports/2017/Overviewof HousinginOntario20170127.aspx

Baines, D. (2011). Chapter 1- An overview of anti-oppressive practice: Roots, theory, tensions. Retrieved from https://www.uvic.ca/hsd/socialwork/assets/docs/2013\%20bswapplications /Chapter\%201\%20-\%20An\%20Overview\%20of\%20Anti-Oppressive\%20Practice_ Final.pdf

Balkissoon, D. (2015, June 19). Unstoppable real estate market displaces Beatrice House shelter. The Globe and Mail. Retrieved from https://beta.theglobeandmail.com/news/ toronto /unstoppable-real-estate-market-displaces-beatrice-house-shelter/article25042379/ ?ref=http://www.theglobeandmail.com\&

Boesveld, S. (2011, September 6). Landlords face no punishment for discrimination in online Ads. The National Post. Retrieved from http://news.nationalpost.com/news/canada /landlords-face-no-punishment-for-discrimination-in-online-ads

Brigham, S. M., Baillie Abidi, C., Tastsoglou, E., \& Lange, E. (2015). Informal adult learning and emotion work of service providers for refugee claimants. New Directions for Adult and Continuing Education, (146), 29-40. doi:10.1002/ace.20129

Brown, D. (2016, September 30). We need more funding to tackle housing crisis, mayors tell feds at Toronto summit. $C B C$. Retrieved from http://www.cbc.ca/news/canada/ toronto/we-need-more-funding-to-tackle-housing-crisis-mayors-tell-feds-at-torontosummit-1.3787046

Burke B., Harrison P. (1998). Anti-oppressive practice. In: Adams R., Dominelli L., Payne M., Campling J. (eds) Social Work. Palgrave, London.

CBC News. (2017, March 1). What Toronto's average monthly rent of $\$ 1,800$ gets you in cities Canada-wide. Retrieved from http://www.cbc.ca/news/canada/toronto/r ent-toronto-canada-1.4002899

Centre for Equality Rights in Accommodation. (2009). “Sorry, it's rented."- Measuring discrimination in Toronto's rental housing market. Retrieved from http://www.equalitrights.org/cera/docs/CERAFinalReport.pdf

City of Toronto. (n.d.). Diversity. Retrieved from http://www1.toronto.ca/wps/portal 
/contentonly?vgnextoid=dbe867b42d853410VgnVCM10000071d60f89RCRD

City of Toronto. (2017, July 26). Daily shelter census. Retrieved from https://www1.toronto.ca/ wps/portal/contentonly?vgnextoid=4ec8c0e9f7301410 VgnVCM10000071d60f 89RCRD\&vgnextchannel=c0aeab2cedfb0410VgnVCM10000071d60f89RCRD

Creese, G. (2010). Erasing English language competency: African migrants in Vancouver, Canada. Int. Migration \& Integration 11, 295-313. doi: 10.1007/s12134-010-0139-3

Crepeau, F., \& Barutciski, M. (1994). Refugee rights in Canada and the 1951 Geneva convention. J. Refugee Stud., (7), 239.

Danso, R. (2009). Emancipating and empowering de-valued skilled immigrants: What hope does anti-oppressive social work practice offer? The British Journal of Social Work, 39(3), 539-555. doi:10.1093/bjsw/bcm126

DaSilva, L. (2016, October 7). New app aims to level Toronto's rental playing field, but who does it help - tenants or landlords?. $C B C$. Retrieved from http://www.cbc.ca/news /canada/toronto/new-rental-app-biddwell-rental-properties-toronto-1.3795193

Derwing, T. M. \& Waugh, E. (2012). Language skills and the social integration of Canada's adult immigrants. Institute for Research on Public Policy, 1-32.

Dominelli, L. (1998). Anti-Oppressive practice in context. In R. Adams, L. Dominelli, \& M. Payne, (Eds.), Social Work, Themes, Issues and Critical Debates. London: MacMillan.

Government of Canada. (2016a, June 16). Government-Assisted refugees program. Retrieved from http://www.cic.gc.ca/english/refugees/outside/gar/index.asp

Government of Canada. (2016b, January 12). Refugee claims in Canada-Options for refused applicants. Retrieved from http://www.cic.gc.ca/english/refugees/inside/refusals.asp

Government of Canada. (2017a, June 16). Asylum claims. Retrieved from http://www.cic.gc.ca/ english/refugees/asylum-claims-made-in-canada.asp

Government of Canada. (2017b, June 6). Immigration and refugee protection regulations. Retrieved from http://laws-lois.justice.gc.ca/eng/regulations/sor-2002-227 /page-27.html\#h-74

Government of Canada. (2017c, May 1). Private sponsorship of refugees program- Information for refugees. Retrieved from http://www.cic.gc.ca/english/refugees/outside/private.asp

Government of Canada. (2017d, June 16). Immigration and refugee protection act. Retrieved from http://laws.justice.gc.ca/eng/acts/i-2.5/page-18.html\#h-53 
Government of Canada. (2017e, May 12). Check application processing times. Retrieved from http://www.cic.gc.ca/english/information/times/index.asp

Government of Ontario. (n.d.). Ontario works. Retrieved from http://www.mcss.gov .on.ca/en/mcss/programs/social/ow/

Immigration and Refugee Board of Canada. (2016a, February 12). About the board. Government of Canada. Retrieved from http://www.irb-cisr.gc.ca/Eng/BoaCom/Pages/index.aspx

Immigration and Refugee Board of Canada. (2016b, January 21). Refugee claims - Claimants. Government of Canada. Retrieved from http://www.irb-cisr.gc.ca/Eng/RefClaDem/ Pages/ClaDem.aspx

Income Security Advocacy Centre. (2016). OW \& ODSP rate increases and the Ontario child benefit. Retrieved from http://yourlegalrights.on.ca/resource/ow-and-odsp-ratesand-ontario-child-benefit-ocb-2016?tid_ref=110

International Organization for Migration. (n.d.). Key migration terms. Retrieved from https://www.iom.int/key-migration-terms

Kirmayer, L. J., Narasiah, L., Munoz, M., Rashid, M., Ryder, A. G., Guzder, J., Hassan, G., Rousseau, C. \& Pottie, K. (2011). Common mental health problems in immigrants and refugees: General approach in primary care. Canadian Medical Association Journal, 183(12), E959-E967.

Kissoon, P. (2010). From persecution to destitution: A snapshot of asylum seekers' housing and settlement experiences in Canada and the United Kingdom. Journal of Immigrant \& Refugee Studies, 8(1), 4-31.

Landlord and Tenant Board. (2017, May). Brochure: 2017 rent increase guideline. Social Justice Tribunals Ontario. Retrieved from: http://www.sjto.gov.on.ca/documents /ltb/Brochures//2017\%20Rent\%20Increase\%20Guideline\%20(EN).html

Leach, Allan F. (1996). Bill 96, tenant protection act. Part 1, introduction 4. (2) and part VI, rules relating to rent, 121. (4) . Legislative Assembly of Ontario. Retrieved from: http://www.ontla.on.ca/web/bills/bills_detail.do?locale=en \&BillID=1482\&Parl SessionID $=36 \% 3 \mathrm{~A} 1 \&$ isCurrent=false

Levitz, Stephanie. (2017, March 1). Canadians have different attitudes on immigrants versus refugees: poll. Globe and Mail. Retrieved from http://www.theglobeandmail.com/ news/national/canadians-have-different-attitudes-on-immigrants-versus-refugees-poll/ article34179821/

Martin, S. (2017a, February 28). Why Toronto's condo rental market is described as 'ridiculous'. $C B C$. Retrieved from: http://www.cbc.ca/news/canada/toronto/why-toronto -s-condo-rental-market-is-described-as-ridiculous-1.4000329 
Martin, S. (2017b, February 28). No fixed address: What's the deal with the 1991 'loophole?' $C B C$. Retrieved from: http://www.cbc.ca/news/canada/toronto/no-fixed-a ddress-what-s-the-deal-with-the-1991-loophole-1.4000965

Massey, D \& Lundy, G. (2001). Use of black English and racial discrimination in urban housing markets: New methods and findings. Urban Affairs Review, 36(4) 452-469.

Matthew House. (n.d.). Our story. Retrieved from http://www.matthewhouse.ca /matthewhouse/page.php?p=about\&s=story

McMahon, T. (2017, January 16). Toronto's hot housing market spills over to condo rentals. Retrieved from https://www.theglobeandmail.com/real-estate/toronto/torontos -hot-housing-market-spills-over-to-condo-rentals/article33627170/

Munro, M. (2003). A primer on accent discrimination in the Canadian context. TESL Canada Journal, 20(2), 38-51. doi:http://dx.doi.org/10.18806/tesl.v20i2.947

Murdie, R. A. (2005). Pathways to housing: The experiences of sponsored refugees and refugee claimants in accessing permanent housing in Toronto. Dept. of Geography, York University.

Novac, S., Darden, J., Hulchanski, D., \& Seguin, A. (2002). Housing discrimination in Canada: The state of knowledge. 1-110. Retrieved from http://www.hnc.utoronto.ca /pdfs/home/Novac_Discrimination-Lit-Re.pdf

Ontario. (1990). Human rights code. Retrieved from https://www.ontario.ca/laws/statute/90h19

Ontario Human Rights Commission. (2009, July 21). Policy on human rights and rental housing. Retrieved from http://www.ohrc.on.ca/en/policy-human-rights-and-rental-housing

Ontario Immigration. (2016, July 4). City of Toronto. Retrieved from http://www.ontario immigration.ca/en/living/OI_HOW_LIVE_TORONTO.html

Oudshoorn, A., Van Berkum, A., \& Michelucci, J. (2016). The role of the housing support worker. Retrieved from http://crhesi.uwo.ca/wp-content/uploads/sites/6/ 2017/02 /Role-of-the-Housing- Support-Worker-1.pdf

Pagliaro, J. (2017, April 25). No new cash for fixing social housing stock. The Star. Retrieved from https://www.thestar.com/news/city_hall/2017/04/25/planned-closure-of-hundreds -of-social-housing-units-called-failure-of-governments-as-waiting-list-grows.html

Robinson, K. (2014). Voices from the front line: Social work with refugees and asylum seekers in Australia and the UK. British Journal of Social Work. 44, 1602-1620. doi:10.1093/bjsw/bct040 
Sakamoto, I., \& Pitner, R. O. (2005). Use of critical consciousness in anti-oppressive social work practice: Disentangling power dynamics at personal and structural levels. The British Journal of Social Work, 35(4), 435-452. doi:10.1093/bjsw/bch190

Sherrell, K., D'Addario, S., \& Hiebert, D. (2007). On the outside looking in: The precarious housing situations of successful refugee claimants in the GVRD. Refuge: Canada's Journal on Refugees, 24(2).

Sienkiewicz, A. (2017, April 22). 'What does it mean for me?' Tenants, landlords full of questions about new rent control rules. $C B C$. Retrieved from http://www.cbc.ca/ news/canada/toronto/rent-control-no-fixed-address-1.4079375

Statistics Canada. (2005). Recent immigrants in metropolitan areas: Canada-A comparative profile based on the 2001 census. Retrieved from http://www.cic.gc.ca/english/ resources/research/census2001/canada/partg.asp

Strier, R. (2007). Anti-oppressive research in social work: A preliminary definition. British Journal of Social Work, 37(5), 857-871.

The Canadian Magazine of Immigration. (2016, March 26). Immigrants in Toronto. Retrieved from http://canadaimmigrants.com/immigrants-in-toronto/

Toronto Community Housing. (n.d.). Who we are. Retrieved from https://www.torontohousing .ca/about/Pages/default.aspx

Teixeira, C. (2008). Barriers and outcomes in the housing searches of new immigrants and refugees: a case study of "Black" Africans in Toronto's rental market. Journal of Housing and the Built Environment, 23(4). doi:10.1007/s10901-008-9118-9

Toronto Community Housing. (n.d.). Who we are. Retrieved from https://www.torontohousing .ca/about/Pages/default.aspx

UNHCR. (n.d.). Convention and protocol relating to the status of refugees. (n.d.). Retrieved from http://www.unhcr.org/protection/basic/3b66c2aa10/convention-protocolrelating-status-refugees.html 